\title{
THE THEORETICAL SYSTEM OF PROPERTY RIGHTS IN CHINA'S GENERAL PRINCIPLES OF CIVIL LAW: THEORETICAL CONTROVERSY IN THE DRAFTING PROCESS AND BEYOND
}

\author{
EDWARD J. EPSTEIN*
}

TABle of Contents

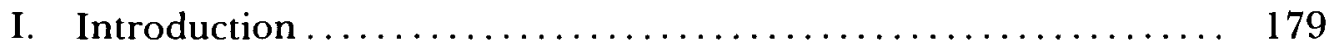

II. System of Property Rights: Introduction ................ 182

III. System of Property Rights:

Ownership and Property Rights Related to Ownership ........ 184

A. Ownership of Property ........................ 184

B. Property Rights Related to Ownership ............... 187

1. Drafting History $\ldots \ldots \ldots \ldots \ldots \ldots \ldots \ldots \ldots \ldots \ldots \ldots \ldots$

2. Theoretical System....................... 188

IV. Property Rights in the State Enterprise ................ 193

A. Influences from the Soviet Bloc .................... 194

B. Theoretical Innovation ........................ 197

1. The Theory of Operative Management Rights ........ 198

2. Theories about New Property Rights .............. 201

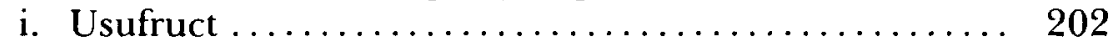

ii. Right to Autonomy ...................... 204

iii. Right to Operate ....................... 205

iv. Ownership Rights ...................... 208

V. Conclusion $\ldots \ldots \ldots \ldots \ldots \ldots \ldots \ldots \ldots \ldots \ldots \ldots \ldots \ldots \ldots \ldots \ldots \ldots, 211$

VI. Afterword $\ldots \ldots \ldots \ldots \ldots \ldots \ldots \ldots \ldots \ldots \ldots \ldots \ldots \ldots \ldots \ldots \ldots \ldots \ldots, 212$

Copyright $\odot 1989$ by Law and Contemporary Problems

* Lecturer in Law, Faculty of Law, University Hong Kong. Since presenting the original paper at Duke University in 1987 I have begun to explore the implications of theories of legal evolution and transplanting for Chinese legal borrowings. I hope to show that the experience in Chinese civil law sheds light on theories of legal transplanting and heritability of law in general but this would have required a complete re-writing of the paper. Instead, apart from the addition of an afterword, this article is substantially the same as the original paper. I would therefore welcome any comment and criticisms which will assist me in this new undertaking. 


\section{ABSTRACT}

China's General Principles of Civil Law ("General Principles") is not just a piece of legislation; it represents a system of legal relations with an underlying theoretical framework. Despite any "Chinese characteristics" that might be found elsewhere in the General Principles, its theoretical framework is firmly rooted in the Romanist legal tradition as interpreted by the Pandectists and borrowed from them by Japan and China before 1949. This is amply illustrated by the definition of property rights in chapter 5 , section 1 .

Parts II and III of this article examine the theoretical tools used by Chinese civil law theorists to draft and analyze these property rights, the system and legal attributes of ownership, and five kinds of "rights in things." The latter are a kind of right in rem. Four of these rights are designed to ensure that the rights to use and realize the economic potential of publicly owned property are distributed to productive economic entities, such as collective or state enterprises and individuals or household economic units. Despite an attempt by legal theorists in the 1950's to shake off the mantle of "bourgeois" legal concepts, the theoretical system used to define these property relations is not Chinese but borrowed from Continental civil law. Sometimes the concepts borrowed from a description of bourgeois property rights, such as possession and usufruct, do not fit the socialist ideal of property relations, but Chinese theorists apply them notwithstanding. Perhaps Pashukanis was right to say that there are no socialist legal forms because law is by definition bourgeois.

The General Principles must also be understood in the context of economic reform in China today. As a fundamental law regulating property relations it has an important role to play in defining the framework of property rights for commercial relations. Yet the theory which is needed to justify and explain these property rights is still the subject of controversy. The lack of a sound theoretical basis for futher legislation to implement economic reform, however, is itself an obstacle to reform. This is illustrated in Part IV of the article which examines in detail the theoretical controversy about the definition of property rights in the state enterprise which affected the drafting of the General Principles and which continues today.

Chinese theories defining the property relations between the state and the state enterprise are examined in four general categories. Theoretical and ideological influences on them are traced, especially to Eastern Bloc countries, and in turn their influence on the drafting process is examined. By and large the theorists have similar ends in mind, i.e., the realization of some degree of economic autonomy for state enterprises to control and deal with their property efficiently and responsibly as their own, with state interference limited to the use of macroeconomic measures. Every school of thought has its own theoretical view of the property rights which define this autonomy. Article 82 of the General Principles represents only one such view and it may well be replaced in the future. Until there is a settled definition, however, it 
will be difficult for a systematic reform of the state-owned industrial sector to take place.

\section{INTRODUCTION}

A common lawyer once remarked that the codification of law in civil law systems was either the consequence of revolution or the function of consolidation. ${ }^{1}$ The drafting of a civil code in the People's Republic of China began in the early 1950's. When the first major draft appeared in 1957 it could have been described as revolutionary, at least in the Chinese context, but despite several revisions it never became law. Still, the draft code and the theoretical mold whence it sprang served both as a basis for studying and teaching civil law as well as a springboard for judicial practice. ${ }^{2}$

China had no civil code in place when in 1978 it began to unveil its new economic policies in agriculture and in 1984 in the secondary and tertiary sectors. There were principles of civil law borrowed from other countries and adapted by Chinese theorists but these principles had no legal basis or agreed upon theoretical framework. Therefore, despite their commitment to the role of law in implementing these new economic policies, China's reformers worked without a civil law, arguably the most fundamental law governing economic relationships, and without the settled theoretical framework which should accompany it. In some ways this was a blessing in disguise because without a rigid legal and theoretical framework, China's reformers, unlike those in some Eastern Bloc countries, have been able to develop more varied and inventive economic forms. In fact, a theoretical basis for action is also of criticial importance to China's leadership, which has become heavily reliant on ideology to mold all manner of social activity. Without it, China's reform policies are difficult to implement and vulnerable to attack. ${ }^{3}$

1. F. Lawson, a Common Lawyer looks at the Civil Law (1953).

2. The most systematic surviving textbook on Chinese civil law from this period is Fundamental Problems of Civil Law of the People's Republic of China by the Civil Law Teaching and Research Section of the Central School for Politico-Legal Cadres, Law Press, Beijing, 1958 [hereinafter Fundamental Problems of Civil Law]. An English translation of parts of this work is available from Joint Publications Research Service Washington, JPRS No. 4879. This translation was not available to the present writer and here all references are to the original Chinese work.

3. What are the reasons behind the failure of China's economic reform? There are several:

1) The absence of a sophisticated and comprehensive theoretical foundation. The economic reforms had already been launched in full scale. How would they change China? Nobody had a clear picture. They simply improvised as they went along. [T] he reformists . . say China's reforms did not have precedents that could act as models. Thus there was no other way than to go about the reforming in a muddleheaded manner. Another excuse was that a sound policy is based upon practical experience; in order to formulate cohesive policies, it is necessary first to have the experience. Thus it is impossible first to draw up a theoretical framework for the implementation of reforms.

Zhang Gang, How and Why is Economic Reform Failing, China Spring Digest, May/June (1987) (Zhang is a local government official engaged in urban economic reform). This may not represent a mainstream view, but I believe it is indicative of the ideological uncertainty facing, in particular, educated progressives in China today. This is underscored by the important ideological innovation which emerged from the Thirteenth Plenary Session of the Central Committee of the Chinese Communist Party in October 1987. That is, China is only in the "primary stage" of socialism and will 
To a Marxist, property rights are the most fundamental legal expression of the system of ownership which determines the economic infrastructure of any society. In a socialist country, property rights, above all, must be properly defined to reflect the radical transition from a system of bourgeois private ownership to the system of state and collective public ownership. As the relations of production change, so too must the law respond by reallocating property rights to new economic entities. Thus, some of the property rights defined in chapter 5, section 1 , of the General Principles ${ }^{4}$ are in direct response to policies of economic reform designed to tap new productive forces in the post-Mao era.

Nevertheless, claims that the General Principles is a "civil law with Chinese characteristics" are prone to exaggeration. ${ }^{5}$ In some arguably more fundamental respects Chinese legal theorists and the drafters of the General Principles have shown themselves to be unimaginative and unwilling or unable to cast off the yoke of Soviet legal doctrine and rigid civil law concepts of the Pandectist School. ${ }^{6}$ Instead of revolution, drafting the General Principles became a process for the rediscovery and exploration of traditional civil law institutions. Yet the product is not a conceptually complete and sophisticated neo-classical legal sculpture such as the German Civil Code ("BGB") which can be admired by the trained legal expert for its precision and rigor of thought.

More than sixty years ago, Pashukanis expressed the view that law is essentially a bourgeois institution and that there are no socialist legal forms. ${ }^{7}$ Debate about the class nature of law has continued in the People's Republic of China and today theorists still argue about the ability of a socialist legal system to inherit or borrow bourgeois legal forms. ${ }^{8}$ The current and

remain there until at least the middle of the next century. According to the former Party General Secretary, Zhao Ziyang, this explains why China cannot leapfrog from a backward economy straight to a stage of socialism with "highly developed productive forces." Nor is it necessary for China to pass through a stage of capitalism, but the via media he thereby seems to suggest is that China has a socialist economy which borrows some capitalist techniques. See People's Daily, Oct. 27, 1987, at 1.

4. Adopted at the Fourth Session of the Sixth National People's Congress on Apr. 12, 1986 [hereinafter General Principles].

5. See, e.g., Shang Ping, Chinese Characteristics of the 'General Principles of Civil Law', Economic Daily, Apr. 19, 1986; Wang Jiafu, General Principles of Civil Law which have Chinese Characteristics, 3 FAxuE YanjiU (STUdies IN LAw) 7 (1983) (such newspaper reports and even journal articles acclaiming the "Chinese characteristics" of the General Principles proliferated at the time of its promulgation).

6. The nineteenth-century Pandectist School consisted mainly of German legal theorists committed to the systematic study of Roman law who "contributed much to the technical sophistication of the BGB" as well as the conceptual jurisprudence of modern European civil law. It was born of the German Historical School of Law, the leading figure of which was Friedrich Carl von Savigny. See K. Zweigert \& H. Koetz, An Introduction to Comparative Law 133-143, 141 (T. Weir trans. 1977), and P. Stein, Legal Evolution 56-65 (1980).

7. E. Pashukanis, Law and Marxism: A General Theory (1924) (B. Einhorn trans. 1978).

8. On Chinese views in the 1950's about the critical inheritance of bourgeois legal form, see Muenzel, Chinese Thoughts on the Heritability of Law: Translations, 6 REv. Socialist L. 275 (1980). For contemporary views, see, for example, Guo, Discussion of the Critical Inheritance of Old Law, 2 FaxuE JIKAN (LAW Q.) 6 (1982). 
"official" view supports the critical inheritance of law, ${ }^{9}$ and in practice Chinese legal theorists study closely and borrow freely the analytical tools of their bourgeois predecessors. The first object of this article is to outline the theoretical system and thus to show how Chinese legal theorists have clung to the analytical tools of bourgeois civil law and have tried with some ingenuity to use them to define ideal socialist legal relationships.

One policy crucial to economic reform in the industrial sector is to make the state enterprise an autonomous economic entity. That is, by defining the property relations between state and state enterprise Chinese reformers hope to separate the state's powers of ownership in state property from the enterprise's own powers to use that property to engage independently in economic activities without state interference. The second object of this article is thus closely related to the first, because I will examine how Chinese jurists have attempted to find a property rights theory to explain the separation of ownership from the use of state property and thus to justify enterprise autonomy. They have used theoretical tools borrowed from a number of sources, and I will attempt to trace these sources and follow the theoretical debate through the drafting process into article 82 of the General Principles, where the property relations between state and enterprise are ultimately defined.

There are, of course, many more theoretical controversies which emerged during the drafting of the General Principles ${ }^{10}$ but these are too many to be included here. Since the purpose of this article is to demonstrate how Chinese theorists hampered themselves by borrowing theoretical tools, it will focus solely on two major issues. Throughout the discussion of these issues, an attempt will be made to integrate the drafting process with theoretical discussions of these or similar issues in published sources. Thus, one may trace the central controversy from various provisions of the drafts of the General Principles into earlier or current scholarly sources or vice versa. In some cases it is not possible to find a direct link between a published view and a given provision of the code; the General Principles was drafted in less than eighteen months, so there was not always enough time for published debate. The issue of property rights in the state enterprise has been chosen for its theoretical and controversial qualities, which have not been settled by the drafting process alone. The controversy will be settled by future theoretical debate if it is ever settled at all.

9. Great Chinese Encyclopedia (LAw) 516 (1984) ("The abrogation of old law and the critical inheritance of [positive and appropriate elements of] old law are the dialectic produced by socialist law.").

10. One writer identified a total of nine subjects of theoretical debate towards the end of the drafting process: (1) the scope of application of civil law; (2) the basic principles of civil law; (3) subjects of civil law; (4) legal persons; (5) rights of ownership and operational autonomy; (6) operation rights; (7) intellectual property rights; (8) periods of limitation; and (9) the relationship of economic law and civil law. See Yang Su, I Studies in Law 39 (1986). To this list we could add conflicts of law and innumerable questions about contractual and delictal obligations. 
II

\section{System of Property Rights: Introduction}

According to Marxist theory, every social epoch is characterized by an economic system of which the most basic feature is a system of ownership. Ownership of property is in turn defined by laws for the protection of property rights. The system of ownership may be defined in a state constitution ${ }^{11}$ or protected by the criminal law. More commonly, however, property rights are most carefully defined and closely regulated by civil and commercial law.

Systematic public ownership of the means of production is the fundamental goal common to all socialist states. In the process of expropriating private owners of productive wealth, however, every socialist state has encountered theoretical problems in legally defining the new property relations thus created. The primary difficulty arises from the use of pre-existing legal concepts which once protected private property but are now applied to public ownership. A major part of this problem is the theoretical and practical difficulty of creating enterprise autonomy, i.e., a system of socialist commerce in which economically independent enterprises can make responsible business decisions while the means of production remains publicly owned. Our task is to discuss both parts of this problem, first by examining how public property rights are accommodated by traditional civil law concepts in the General Principles, and second by focusing on theoretical debate about the nature of property rights in the state enterprise.

Roman law distinguished between ownership (dominium) and property rights less than ownership, such as various forms of possession, servitudes, and usufruct. ${ }^{12}$ Such distinctions were functional, however, and it was the French Civil Code and then later, more completely, the Buergerliches Gesetzbuch ("BGB") which adopted a formal classification of property rights. ${ }^{13}$ At this point a common lawyer may want some explanation of this civil law system of classification. Put crudely, civil law regulates status (that is to say, the ability to engage in civil activities) and property relations. The latter include all kinds of property rights whether relative, arising by virtue of obligations in contract, tort, or some other conduct between persons, or absolute, arising by virtue of some legally recognized form of domination over a thing.

11. This is most often the case in socialist countries where the state constitution is at first a revolutionary document; see, e.g., Constitution of the People's Republic of China, art. 6 (1982); Constitution of the Federal. Socialist Republic of Yugosiavia, art. 6 (1963).

12. See P. Stein, Legal Institutions: The Development of Dispute Setrlement $144-72$ (1984)

13. The French Civil. Code, as amended to July 1976, Bk. 2, Property and Different Types of Ownership at 129 (J. Crabb trans.); The German Civil Code, as amended to Jan. 1975, at 143 (I. Forrester trans.). 
"Rights in things" are distinguished from other property rights by two important features. 14 First, "rights in things" confer rights on a particular person (e.g., an owner, possessor, mortgagee, and so on) rather than a class of persons (e.g., creditors in a bankruptcy or victims of a tort). The object of the right is a "thing," that is, physical property, normally classified as immovables (i.e., land and fixtures) and movables (i.e., goods), but not intellectual property or property rights which arise from the conduct of another person (e.g., a debt or action in tort). In other words, the law over things regulates the relationships between persons and things while the law of obligations regulates the relationships between persons inter se. The closest approximation in the common law is the distinction between "real" rights and "choses in action."

Second, "rights in things" allow the domination of a thing to the exclusion of the rest of the world. This is because the right inheres in the thing itself without the need for any legally recognized relationship between persons like that existing between parties to a contract or between the tortfeasor and his victim. For the same reason, the holder of such a right has a remedy against the thing itself, not merely an action in damages. The last distinction will be most familiar to those schooled in the common law with its history rooted in the forms of actions.

The BGB had a profound effect on the drafting of the 1896 Japanese Civil Code, ${ }^{15}$ and it was largely through Japan that the Civil Code of the Republic of China, published between 1929 and 1931, acquired its terminology for the classification of property rights. ${ }^{16}$ Like its German and Japanese counterparts, Book 3 of the Republican Code is entitled "Rights in Things" (wuquan), ${ }^{17}$ and deals with ownership, possession, hereditaments, servitudes, liens, the right to water fees, charge and mortgage, as well as related matters such as joint ownership and registration of rights. ${ }^{18}$ As any civil lawyer would

14. On this topic see generally Great Chinese Encyclopedia (LAw) 628 (1984); V. Riasanovsky, Chinese Civil Law 186 (1938) (reprinted by University Publications of America 1976); 1 E. Cohn, Manual of German Law 170 (2d ed. 1968).

15. "[F]ew doubt today that the [Japanese] Civil Code of 1896 is not a carbon copy of the German code." Noda, Comparative Jurisprudence in Japan: Its Past and Present, in ThE JAPANESE LEGAL System 209 (H. Tanaka ed. 1976).

16. The facility of Chinese scholars to study Western materials in Japanese rather than in the original language is still well recognized today. Thus, it was a combination of the experience of Chinese students in Japan and Japanese legal experts in China which influenced the theory and drafting of, first, the reformist codes of the late Qing Dynasty and, then, the codes of the Republic of China. See Henderson, Japanese Influences on Communist Chinese Legal Language, in Contemporary Chinese law: Research Problems and Perspectives 158 (J. Cohen ed. 1970). On the origins of the Civil Code of the Republic of China, see also Sheng, The Civil Code of China, 4 Chinese L. REv. 69 (No. 4 1930); Cheng, Recent Legislation in China 4 Chinese L. Rev. 117 (No. 5 1930).

17. The German term is "Sachenrecht," BGB Bk. 3, supra note 13, and the Japanese term is "bukken," Bk. 2 Japanese Civil Law, in Hiragana Shoroppo (Collection of Six Legal Codes of Japan) 75 (Ito Akira ed. 1987); The Civil Code of Japan 31 (1984).

18. Civil Law and Related Legislation, in Zuixin Liufa QUanshu (Latest Complete Book of Six Coovs) 158-66 (as amended to Sept. 1986) (Baichuen T'ao ed.) (in Chinese). 
appreciate, these are rights in the things themselves and not merely actions, which are relegated to the category of "obligations" (zhai). ${ }^{19}$

Instead of the familiar civilian division between "things" (viz., property rights) and "actions" (obligations), drafters of the General Principles adopted an unusual distinction between "civil rights" and "civil liability." The seeds for this novel system of classification appear in the fourth draft of the civil code, which divided the law of obligations into contract and other "civil liability." 20 The early "draft for comments" of the General Principles first used the new classification, and it remained unchanged throughout the drafting process. ${ }^{21}$ There are four categories of civil rights: (1) "ownership and property rights related to ownership;" (2) "obligations;" (3) "intellectual property rights;" and (4) "personal rights."

\section{III}

\section{System OF Property Rights: OWNership and Property Rights Related to OWNERSHIP}

At first glance, the classification of "rights in things" is conspicuously absent from the General Principles. But closer examination reveals signs that the theoretical concept is still hard at work. Indeed, despite earlier attempts to abandon it, Chinese legal theorists are still bound to the concept of "rights in things" and in some cases are even creating new types of real rights.

\section{A. Ownership of Property}

The early systematic exposition of Chinese socialist civil law rejected ${ }^{22}$ the concept of "rights in things" (wuquan) in favor of a concept of ownership of property divided into three constituent "powers and functions" (quanneng): possession (zhanyou), use (shiyong), and disposition (chufen). ${ }^{23} \mathrm{~A}$ fourth constituent was added to the textbooks recently: "the right to benefit"

19. Id. Bk. 2

20. The fourth draft of the PRC civil code was circulated in 1982. An English translation appears in Jones, $10 \mathrm{REv}$. Socralist L. 193 (1984). For an introduction to the drafting history of the General Principles and its relationship to the draft civil code, see Epstein, The Evolution of China's General Principles of Civil Law, 34 Ам. J. Comp. L. 705 (1986).

21. The "draft for comments" is dated Aug. 15, 1985. For an understanding of its place in the drafting process see Epstein, supra note 20, at 711 .

22. "[T]he Guomindang law on rights in things is a reproduction of the reactionary civil legislation of capitalist and imperialist countries, [and] at the same time preserves the old Chinese feudal concept of rights in things." [sic] See Fundamental Problems of Civil Law in the People's REPUBLIC OF China, supra note 2, at 118 . Until recently, civil law textbooks only discussed "things" $(w u)$ but not "rights in things" (wuquan), see Tong Rou, Minfa yuanli (Principles of Civil Law) 124 (1st ed. 1983) [hereinafter Tong R. 1]. Now it is acceptable to discuss "rights in things," see Tong Rou, Principles of Civil Law (2d ed. 1985) [hereinafter Tong R. 2].

23. "Although possession, use, and disposal are the content of ownership, if one or two [of these powers and functions] is detached from the owner or is limited [this] will certainly not mean that the owner has thus lost ownership." Fundamental Problems of Civil Law, supra note 2, at 124. See also Tong R. 1, supra note 22, at 124. 
(shouyiquan). ${ }^{24}$ It seems from current textbook writers that possession or use are not prerequisites to enjoying the right to benefit. ${ }^{25}$ This clearly allows for the enjoyment of "unearned" income, which was anathema to civil law theory in the late 1950's. ${ }^{26}$ All four "powers and functions" now constitute the elements of ownership as defined in article 71 of the General Principles. ${ }^{27}$

These four constituent powers and functions of ownership can be distilled from ownership individually or in combination, but even so they will not necessarily become independent property rights. ${ }^{28}$ Some theorists assert that ownership is not just the sum total of these constituents; it is the overall right to control property which can itself be reserved to an owner after the other constituents have been separated out. ${ }^{29}$ Why do Chinese theorists analyze ownership in this way? The point is that by breaking ownership down into four constituent parts theorists can build new rights with novel combinations of the old parts. This might be described as a process of borrowing bourgeois theoretical tools to produce new "socialist" legal concepts. ${ }^{30}$ It is shown below to what extent this process has been successful.

In accordance with the 1982 Constitution, ${ }^{31}$ the General Principles divides the system of ownership into three categories: by the whole people, by collective organizations of the working masses, and by citizens. The bulk of the means of production is publicly owned by "collective organizations of the working masses" 32 or by "the whole people." 33 At first glance this appears to

24. See Tong R. 2, supra note 22 , at 141 .

25. Id.

26. Examples of the exercise of the "right to benefit" given by the current textbook writers include rent from the hire of private premises, id., interest from savings and eggs from chickens; see Zhonghua ReNMin gongheguo minfa tongze shiYi (Explanatory Notes on the General Principles of Civil Law) (Zhou Y. ed. 1986). Compare this view with the one from the 1950's:

We can see this point [that the Guomindang system of property rights is a tool for the exploitation of the working people] right from the provision for "rights to benefit" (shouyiquan) in their [the Guomindang] ownership rights. Here, they ingeniously explain away a property owner's source of [unearned] income as "statutory fruits" or "natural fruits" and thereby the exploiting classes use their "benefit" to disguise what is really the extraction of blood and sweat from the working people.

Fundamental Problems of Civil Law, supra note 2, at 188.

27. "Ownership means an owner's right in accordance with law to possess, use, benefit from, and dispose of his own property." General Principles of Civil Law of the People's Republic of China, 34 AM. J. Comp. L. 715-43, 729 (W. Gray \& H. Zheng trans. 1986), reprinted in LaW \& Contemp. Probs., Spring 1989, at 27.

28. For example, one legal theorist laments the fact that in Chinese civil law the right of possession is not itself sufficient to support an action asserting a better right to a thing than a third party's; such an action must be brought by its owner. See Wang Liming, Problems Concerning Possession, the Right of Possession and Ownership, 1 Faxue PINGLun (LAW REv.) 15 (1986) (bimonthly journal of Wuhan University Law Department).

29. Zhipei quan; see Wang Liming, Discussion of Commodity Ownership, 2 STUdies IN LAw 37 (1986), and Li Yuanzhi, Trial Discussion of Ownership's Internal Vertical and Horizontal Structure, 1 STUdIEs IN LAw 51 (1986). This is the same view propounded by Wang Liming and Liu Zhaonian in the accompanying article, The Property Rights System of the State Enterprises in China, LAw \& ConTEMP. Probs., Summer 1989, at 19.

30. Supra note 8 and accompanying text.

31. Constitution of the People's Republic of China, Chap. 5, $\$ 1$, arts. $73-75$ [hereinafter ConST.]. This system of classification was also adopted in textbooks and the 1982 draft of the civil code.

32. Laodong qunzhong jiti zuzhi. Id. art. 74. 
be nothing out of the ordinary in the family of socialist civil codes. Closer examination reveals a number of important differences. For example, unlike the Soviet codes, China's General Principles expressly permits private ownership of the means of production "within the limits of the law." 34

For present purposes it is important to note that the Chinese civil law drafters seemed to be moving away from the Soviet concept of "state ownership," i.e., that "the state is the sole owner of state property," 35 towards the more flexible notion of "state property" which "belongs to the whole people." 36 According to the Soviet analysis, for the state to enjoy property rights it must be a subject of civil law, which is a status usually reserved for natural and legal persons. To be sure, Chinese theorists have consistently accepted the theory that the state is at once the subject of both sovereign and civil rights. ${ }^{37}$ This was expressly provided in the fourth draft of the civil code $^{38}$ and can be inferred from the provisions on ownership in the first three drafts of the General Principles. ${ }^{39}$ The final draft, however, replaced state ownership (guojia suoyou) with the present concept of state property owned, not by the state, but by the whole people. Therefore, one can argue that because state property is owned by the whole people, the state need no longer be viewed as a subject of civil rights at all. ${ }^{40}$ Here was an opportunity for theoretical creativity. With the state removed from the sphere of civil activities, there are solid theoretical grounds on which to argue that the property in a state production enterprise belongs to the whole people, and, as the enterprise is the only entity with legal status to engage in economic relations with this property, the state has no power to interfere with it. Instead, the drafters appear to have created a distinction without a difference.

Chinese economic and legal theorists have in recent years focused their attention on the special features of Yugoslavia's non-conformist socialist economic system. Therefore, it cannot be a coincidence that this apparent

33. Quanmin. Id. art. 73

34. Id. art. 75 .

35. Fundamental Principles of Civil Legislation of the USSR and the Union Republics, The Soviet LegaL SySTEM 400, art. 21 (W. Butler trans. 1978).

36. See Const., art. 73. Art. 7 of the 1982 Constitution merely provides for the public economy as "ownership of the whole people economy." The third major feature of the system of ownership expressed in the Chinese code is the collective ownership of land. Id. art. 74(1).

37. See Fundamental Problems of Civil Law, supra note 2, at 172; Tong R. 2, supra note 22, at 34, 159; or for a more recent exposition, see two works by Professor Jiang Ping, a Soviet trained civil law specialist who graduated from the Law Faculty, University of Moscow, in 1956: Minfa jiaocheng (Textbook of Civil LaW) 50-51 and Minfa tongze jianghua (Lectures on the General Principles of Civil LaW) 129-131 (1986).

38. "The state is a special subject of civil law when it represents the interests of the whole people when engaging in civil activities." Chinese Civil Code, Bk. 2, Chap. 4, art. 46.

39. These drafts consistently referred to "state ownership," sometimes of various objects, as in article 72 of the third draft which provided seven objects of "state-owned" property, including all manner of enterprises.

40. Except in the rarest of cases, for example, where the state inherits property for lack of any entitled heir. See Inheritance Law of the PRC, art. 32, in Zhonghua Renmin gongheguo fagui huibian (Collection of Laws and Regulations of the PRC) (1985). 
departure from the Soviet view reflects the influence of the Yugoslavian concept of "social property."

The essence of social property may best be explained in negative terms, that is, that it is neither state, nor private, nor personal property. ${ }^{41}$

Yugoslav writers claim that this view is a positive step away from state property because it precludes any person or entity (including the state) from monopolizing the means of production and thereby prevents exploitation, which occurs when the surplus value of the workers' labor is alienated by a third person. ${ }^{42}$ This may be attractive as a political ideal, but as a legal concept it is confusing because, according to the popular view, "social property" cannot be owned by anyone at all.43 It belongs exclusively to society for the use of the workers who thereby retain control over the products of their own labor. The transition from state to social property in Yugoslavia was accompanied by economic liberalization, the purpose of which was to allow the workers in "economic" enterprises a measure of selfgovernment. ${ }^{44}$ The idea is therefore potentially attractive to Chinese economic reformers who have similar goals in mind. However, as outlined below, in the quest to expand enterprise autonomy Chinese legal theorists have largely upheld Soviet doctrine.

\section{B. Property Rights Related to Ownership}

Having thus vested ownership of most productive wealth in state and collective entities, many of which do not even have an economic function, four articles of section 1 are devoted to a system of legally separating out the rights and functions of property ownership and distributing them to economically productive entities such as state and collective enterprises, and even individual farmers or entrepreneurs. Even if only the bare bones ${ }^{45}$ of a system of rights in things, this part demonstrates the debt the drafters owe to the German theoretical system.

1. Drafting History. The "draft for comments," which was a product of some theoretical but mainly practical input, provided compendiously for the legal protection of all kinds of civil rights, including the right to use property (shiyong quan), the right to use land according to a contract (chengbao quan), the

41. A. Chloros, Yugoslav Civil Law 161 (1970).

42. Yugoslanian Encyclopedic Dictionary of Law 3-17 (L. Huang Chinese trans. 1979 ed. $[1984])$.

43. Id. at 14 .

44. A. Chloros, supra note 41 , at 163 .

45. Section 1 reflects only the very basic property relations in China's economic system. Other rights are not included, for example, rights to use land in the course of foreign investment, which is nevertheless the subject of separate legislation. See, e.g., Provisional Regulations for the Administration of Land in Shenzhen Special Economic Zone (1981), in ZhongGuo SHEWAI JINGJI fagui huibian (Collection of China's Foreign Economic Legislation) (1949-1985) (1986) (Similar legislation exists in Xiamen and Tianjin.). Nor does it protect the right to use land on which a home has been built (zhai jidi shiyongquan), which is a controversial issue, particularly among China's increasingly wealthy peasants, and was provided for in earlier drafts. For a more complete and traditional catalogue of "rights in things," see ToNG R. 2, supra note 22, at 149-57. 
right to operate property (jingying quan), the right to create a pledge (diya quan), ${ }^{46}$ and neighborhood rights (xianglin quan) over property. ${ }^{47}$ In five further articles the draft expanded on the nature of some of these rights, and eight out of thirteen articles in this section were concerned exclusively with real rights. The next draft was in similar but slightly expanded form and was presented by Wang Hanbin to the Thirteenth Session of the Standing Committee of the National People's Congress on November 13, 1985. He stressed the importance of these property rights in "meeting the needs of economic reform." 48

The following draft, then, was a product of the deliberations of the Thirteenth Standing Committee and a meeting of 180 legal experts. ${ }^{49}$ The draft adopted the existing system of classifying civil rights into four sections although the existing content was finally settled by the National People's Congress only after many changes were made to the first four drafts. Therefore, while the content of the drafts was affected by both practical and theoretical input, the system for organizing and expressing property rights was largely a product of theoretical input, particularly by the conference of experts held after the second draft was circulated.

2. Theoretical System. After setting out ownership rights and related matters, section l enumerates five "property rights related to ownership" in articles 80 to 83. Although perhaps officially abandoned, the concept of "rights in things" was still clearly in the minds of drafters who suggested how these five rights should be set out and remains in the minds of writers who are now called upon to explain them..$^{50}$ They are as follows:

1. The right of state-owned or collective units "to use and benefit from" (shiyong shouyi) land owned by the state [art. $80(1)]$ or things on the land owned by the state [art. 81(1)];

2. The right, acquired by contract, of citizens or collectives to operate publicly owned land [art. 80(2)] and things on the land (chengbao jingying quan) [art. 81(3)];

3 . The right of state or collective units or citizens to exploit natural resources (caikuangquan) [art. 81(2)];

4. The rights of an enterprise owned by the whole people (viz., a state enterprise) to operate property given to it by the state (jingying quan) [art. 82]; and

5. limitation of property rights necessary for the conduct of "neighborhood relationships" [art. 83].

The first four of these civil rights perform an important economic function because they create a mechanism to define, even if only sparingly, the legal

46. The pledge is included among provisions on obligations in the General Principles, even though they give rise to real rights such as the right to sell charged property where the creditor is unpaid, see discussion of art. 89(2), infra, at 192-93.

47. Art. 47.

48. Wang Hanbin is the Chairman of the Standing Committee's Secretariat and the Committee for Law Building Work. China Legal News, Nov. 18, 1985, at 2.

49. See Epstein, supra note 20, at 712 .

50. Two writers have even suggested that the General Principles now provides the basis for creating a socialist system of "rights in things." See Li \& Qian, Preliminary Discussion of Our Country's Civil Law System of Rights in Things, Beijing daxue xuebao (BejJing Univ. Rev.) 117 (phil. ed. 1987), reprinted in Fuyin baokan ziliao (Faxue) (Reprints of Newspaper and Journal Materials (Legal STUDIES)) D4I, 2, 45 (1987). 
rights of productive entities to control the publicly owned means of production. In his Theories of Surplus Value Marx showed that under capitalism lesser property rights were separated from the ownership of capital thereby realizing its economic function.51 The division between the legal and economic functions of ownership becomes even more important in a socialist economic system where most of the means of production are legally owned by non-production entities. In the People's Republic of China this division was also recognized at an early stage; 52 but it was only in the drafting of the General Principles that the division was crystallized into a system of property rights recognized by the civil law. ${ }^{53}$

A number of commentaries on the General Principles have recently appeared, some of which are of sufficient theoretical sophistication to reveal the thinking behind this classification of property rights. Two of them deserve special examination.

Ownership of property is one type of most comprehensive rights in things. Apart from this there are still many property rights ... [which] do not possess all the features and content of ownership, but ... . are still a very important type of civil rights. To protect these property rights conscientiously ... is very important indeed in order amply to realize the usefulness of things . . . 54

Our country's General Principles of Civil Law have not explicitly provided for rights in things, but the ownership rights and property rights related to ownership stipulated in chapter 5 , section 1 are essentially rights in things. . . 55

The writers then go on to classify and discuss the five property rights listed above.

First, there is the right of state and collective units to use and benefit from land or things on the land owned by the state. In classic civil law terminology this right is described as a usufruct (yongyiquan): ${ }^{56}$

Usufruct means that a citizen or legal person, called the usufructary, enjoys the legal right to use and receive the benefit from the property of a third party. [T] he object of a usufruct relationship is always non-fungible. During the usufruct relationship the usufructary has the right to possess, use, and benefit from the thing according to law [and] to reject interference and obstacles created by third persons. Also, the usufructary has a

51. Quoted by Lu Zhengping, Brief Discussion of the Duality of Ownership in the Property of Enterprises Owned by the Whole People, 3 LAw Q. 36, 37 (1986) (Journal of the Southwest Inst. of Politics \& Law).

52. An early example of this division of property rights is an oft-cited set of regulations allowing private individuals or cooperatives to enjoy the right to benefit from the use of uncultivated land owned by the state. "During the [land] use period, the state safeguards the private entrepreneur's right to use the land and enjoy lawfully earned benefits." Regulations for Overseas Chinese to Apply for the Use of State-Owned Uncultivated Mountains and Lands, in 2 Collection of Laws and Regulations of THE PRC, art. 4(2) (July-Dec. 1955).

53. To be sure, the 1982 draft civil code contains the seeds of these property rights but not the theoretical system; see, e.g., civil code draft arts. 48, 82, 91, supra note 20 . However, the theoretical system can now be found in the standard civil law text edited under the supervision of the Legal Studies Editorial Board, see supra note 24. The system can also be found in textbooks on civil law published by two leading Chinese universities: Tong Rou, INTRODuCTION TO Civil Law (1982), and Wang Z., Minfa jiaocheng (Civil Law Textbook) (1982).

54. Hu S., Minfa tongze jianghua (Lectures on the General Principles of Civil Law) 197 (1986) (emphasis added).

55. Ye L., Chengbao jingyingquan 3 (1986) (right to operate public property under contract) (emphasis added).

56. BGB Book 3, Chap. 5, Part 2; Civil Code, Bk. 2, Chap. 3, Pt. 1, supra note 13. 
corresponding obligation to protect, manage, and use the thing properly, and to return it when the usufruct has expired. 57

The relationship between the state and a socialist economic entity is thus described in the same terms as the relationship between a private landowner and a usufructary.

Second, there is the right, acquired by contract, of a citizen or collective to use publicly owned land and things on the land and to enjoy the fruits. This right is the cornerstone of China's agricultural reforms. ${ }^{58}$ It has also been described as a kind of usufruct.

The contract usufructary (chengbaoren) directly occupies [and] uses the land, forest, and like natural resources owned by the state or collective ... and after fulfilling his duties to meet state purchasing [targets] and pay agricultural taxes [and] make [agreed] payments to the collective he is entitled to receive the entire benefit. Therefore, this is a type of usufruct. ${ }^{59}$

The contractual usufruct, as I shall call it, differs from the first type of right to occupy and use land because the right arises from a contract between the usufructary and the owner or occupier of the land, not by operation of law. ${ }^{60}$ The terms of the usufruct may vary according to the agreement between the parties, but certain rights and liabilities are present in every usufruct regardless of the contract terms. These include the usufructary's right to occupy and enjoy the benefits from the land without interference from the other party but always subject to the duty to respect public ownership of the land, environmental protection, and the relationship between himself and the agricultural collective and third parties. ${ }^{61}$ Common lawyers might call these implied terms which the parties cannot agree to exclude, but here the terms are contained only in the theoretical interpretation of the right, not in a statute.

The contractual usufruct also resembles the BGB concept of a "usufructary lease," 62 although strictly speaking no rent is payable on a contract usufruct. Consideration for the use of the land is provided by the usufructary in the form of a share in the fruits from the land or by payment of use fees. ${ }^{63}$ No matter how long the contract period, the heirs and successors of the so-called "usufructary" cannot inherit the right to continue to use the land and enjoy its fruits. ${ }^{64}$

57. See Hu S., supra note 54, art. 197 (emphasis added). See also the definition of a usufruct in article 578 of the FRENCH CODE CiviL: "Usufruct is the right to enjoy things of which another has ownership like the owner himself, but with the substance of conserving the substance of it." J. CrabB, supra note 13 , at 138 . 101 .

58. Chang, Rural Responsibility Production Contracts, Law \& Contemp. Probs., Summer 1989, at

59. See YE L., supra note 55 , at 4.

60. Id. at 10 .

61. Id. at $31-37$.

62. BGB, Bk. 2, § 7, tit. 3 .

63. In substance, however, it is difficult to distinguish this type of payment from a payment in rent.

64. See The Right to Contract Use of Land Cannot be the Subject-Matter of Inheritance, 2 Falü JIANSHE (Legal Construction) 14. See also BGB, art. 1061, which provides that the usufruct is terminated by 
The third property right, to exploit publicly owned natural resources, is distinguished from the usufruct and defined as a "right to exploit resources" (caikuang quan).

\begin{abstract}
Although this provision has the same legislative objective as the usufruct, the object of the right to exploit resources is completely different from the object of the usufruct; the former is a fungible, the latter is not. [D]uring the process of exploitation [the resources] are continuously reduced. Therefore, the state implements a system of compensation for exploitation of mineral resources [and] has the right to levy certain fees. . . .65
\end{abstract}

In Roman law it was theoretically impossible to create a usufruct over property which would be consumed (a fungible), but the problem was overcome by allowing the usufructary to become the owner of the fungible and imposing a duty to restore an equivalent amount to the original owner. ${ }^{66}$ This is the solution adopted in the BGB. ${ }^{67}$ In Chinese civil law, however, it is theoretically impossible for the state to lose its right of ownership in natural resources, even after they have been removed from the ground. The surplus fruits of the contract usufruct belong to the usufructary ${ }^{68}$ but mineral resources are not fruits of the land; they are the land itself. The Chinese theoretical position, following Soviet doctrine, has always been that state property is inalienable. ${ }^{69}$ However, by levying fees on those units or persons exploiting state-owned mineral resources it appears the state is effectively transferring ownership to them. Indeed, it is hard to imagine what right other than ownership is being transferred when resources are sold to third parties. It shall be seen later that the same theoretical dilemma arises in connection with state property under the control of state enterprises. ${ }^{70}$

The fifth type of property right listed above, the neighborhood right, was conspicuously absent from the early textbooks but was later reintroduced in the name of rights for the reasonable conduct of "neighborhood relationships." 71 This type of property right was covered in some detail in the draft civil code ${ }^{72}$ but just one article was included in the General Principles to cover a wide range of rights for the prevention of disputes between neighbors. ${ }^{73}$

In the case of immovable property, all neighbors must in accordance with the spirit of harmony and mutual assistance, and fairness and reasonableness, and in the interests of facilitating production, making life more convenient, and correctly conducting neighborhood relationships such as those with respect to water supply, passage, air,

the death of the usufructary, and similarly Code Civil, art. 617 (France), and Civil Code of The RePublic of China, art. 1204.

65. Hu S., supra note 54, at 199.

66. P. Stein supra note 12 , at 153 .

67. BGB, art. 1067.

68. YE L., supra note 55, at 2.

69. The Soviet Legal System, supra note 35.

70. See infra at 208-11.

71. Tong R. 1, supra note 22 , at 170-76.

72. Arts. 108-21.

73. Art. 83 
and light. A person who with respect to his neighbor causes an obstruction or damage must cease any infringement, eliminate any obstruction, [and/or] pay damages. ${ }^{74}$

Such rights arising in the interest of harmonious neighborhood relationships are property rights only in the sense that they limit the exercise of property rights by the owner or occupier of a neighboring immovable. They place on neighbors both positive and negative duties to avoid disrupting each other's use and enjoyment of their own property. This is how these rights are classified in both Japanese ${ }^{75}$ and Chinese Republican ${ }^{76}$ civil codes. Riasanovsky argues that these rights must not be confused with servitudes. ${ }^{77}$ The former merely limits the way a right is exercised, but the servitude creates a new right over the property of one neighbor in favor of, and vested in, the property of the other. This distinction, while valid in principle, is of little practical significance ${ }^{78}$ and becomes blurred in the following passage.

Neighborhood relationships . . . in the Japanese civil code are called "limitation of ownership;" $\left[{ }^{79}\right]$ in the civil code of the German Democratic Republic there is a chapter devoted to the relationships between users of neighboring immovables. $\left[^{80}\right]$ In the French "Code civil" it is provided among "servitudes or real servitudes." [81] But whatever it is called, it means that when exercising their lawful rights the owners or occupiers of adjoining property shall respect the other owner's or occupier's rights. ${ }^{82}$

The term "neighborhood relationships" has been derived from terminology used in the Republican Civil Code, ${ }^{83}$ which contains provisions similar to those in the Japanese code mentioned above.

Like their equivalents in other civil law systems, neighborhood relationships give rise to rights which, as common lawyers would put it, "run with the land." 84 They are rights which arise from the need to preserve harmony between owners or occupiers of immovable property in the exercise of their property rights and they do not extend beyond this need. ${ }^{85}$

It was noted above that the General Principles does not include every kind of real right which is recognized in Chinese legislation or legal theory. However, chapter 5 , section 1 , contains all those real rights which are defined, with one exception. Section 2 deals with obligations, and article $89(2)$ provides that certain property may be offered as a pledge (diya) to secure performance of a civil obligation. The pledge creates a real right because it entitles the obligee

74. General Principles of Civil Law of the People's Republic of China, supra note 27.

75. Arts. 209-38.

76. Arts. 774-98

77. V. Riasanovsky, supra note 14 , at 210.

78. Earlier drafts of the General Principles stipulated a "neighborhood right" (xianglin quan); but this term was later abandoned, although it remains in use in some textbooks. Tong $\mathbf{R}$. 2, supra note 22 , at 192 .

79. The Civil Code of Japan, supra note 17, Bk. 2, Chap. 3, Sec. 1, arts. 209-38.

80. ZGB Bk. 4, Chap. 6 (East Germany).

81. Bk. 2, Chap. 4 , supra note 13 , at 84 .

82. WANG Z., supra note 53 , at 189.

83. See Bk. 3, Chap. 3, art. 833. This article incorporates the provision limiting the exercise of ownership set out in arts. 774-798.

84. Hu S., supra note 54, at 202.

85. Id. See also BGB, arts. 1018 \& 1019 , which set out the concept and limitation of servitudes in similar terms. 
to sell and realize the value of the property if the obligation is not performed. Therefore, although the drafters did not include it among property rights in section 1 , it is clear that they also intended the pledge to be treated as a real right. ${ }^{86}$ The terms pledge (diya) and pledged property (diyawu) are also used in Book 3 of the Chinese Republican Civil Code, but only to denote a pledge of immovable property without the transfer of possession. ${ }^{87}$ The usage in the General Principles, however, appears to be applicable to any property; but it is not clear whether the obligee must have possession of the property to realize its value. ${ }^{88}$

Having defined China's mixed system of ownership, chapter 5 , section 1 , breaks ownership rights down into four types of property rights. These rights are designed to ensure that economically productive entities can utilize the means of production owned by the state or economically defunct collectives and can thereby realize its economic value. Chinese civil law theorists call these rights in things. Overall, despite an initial attempt to shake off the mantle of "bourgeois" classification, clearly the General Principles remains committed to the civil law system of property rights, influenced particularly by the codes in those countries which have adopted the German theoretical system.

The next section examines in detail the property rights in the state enterprise and the theoretical debate about their definition.

\section{IV}

\section{Property Rights in the State Enterprise}

It must always be remembered that the current theoretical debate about property rights in the state enterprise is a debate about how to define and realize enterprise autonomy in a socialist planned economy. Enterprise autonomy should mean that the enterprise is able not only to resist interference from state administrative organs in its production and commercial activities but also can use state property as responsibly as an entrepreneur would use his own. Both aspects of enterprise autonomy depend on the definition of the property relationship between the state, the legal owner of all property which belongs to the whole people, and the state enterprise, which has immediate economic control over state property. China

86. See e.g., Li \& Qian, supra note 50.

87. Bk. 3, Chap. 6.

88. The only specific legislation on loan securities in China provides that both movable and immovable property (including obligatory rights) may be pledged as security. Although actual possession is not transferred to the obligee, the pledged property must be registered; and it is with the authority of the registration organ that the obligee can take steps (e.g., to auction) to realize the value of the pledged property. See Regulations for the Administration of Secured Loans in Shenzhen Special Economic Zone (1985), in Collection of China's Foreign Economic Legislation, supra note 45, at 1008. For a translation and discussion of 1988 land-use legislation in Shanghai which includes provisions on the mortgage of land-use rights and immovables, see Sobel \& Zhang, The Evolution of Foreign Secured Lending in China, Law \& Contemp. Probs., Summer 1989, at 185 \& App. 
has chosen the General Principles to define this relationship; and other recent legislation to implement enterprise autonomy hinges on this definition. ${ }^{89}$

The problem of enterprise autonomy in socialist countries has usually arisen during periods of economic readjustment. ${ }^{90}$ Unlike the Soviet Union and some other Eastern Bloc countries, however, China has only recently begun to define enterprise autonomy. This is partly due to the fact that China's new economic policy is a relative latecomer. As China departed much earlier from the Leninist model of expropriation, more of capitalist industry was preserved, at least until 1958, than could otherwise have been expected.91

\section{A. Influences from the Soviet Bloc}

Eventually, however, China adopted Stalin's model of economic management ${ }^{92}$ and from this time Chinese legal theory on the rights of an enterprise in state property, like that of many Eastern Bloc countries, ${ }^{93}$ was also formed in the mold of Soviet doctrine. ${ }^{94}$ From the outset, some theorists have argued that the state was the only proper subject capable of enjoying ownership of property which belongs to the whole people. Therefore, despite its sovereign status, the state was treated as the subject of civil law relations

89. See, e.g., Work Regulations for Factory Managers of Industrial Enterprises Owned by the Whole People (Oct. 5, 1986), 1 Guowuyuan gongbao (Bull. State Council) (1987) (English translation in Summary of World Broadcasts, Far East, Jan. 21, 1987, at 1, col. 1); [State-Owned] Enterprise Insolvency Law (adopted by the 18th Session of the 6th National People's Congress, Dec. 2, 1986 (Trial), People's Daily, Dec. 3 , 1986) (English translation in Summary of World Broadcasts, Far East, Dec. 6, 1986). On the system of leasing state commercial enterprises to contract management by collectives and individuals, see State Council Notice Approving the Report by the Ministry of Commerce on Certain Problems in the Current Reforms of the Commercial System in Cities, in Xianxing fagui huibian (Collection of Current Laws and Regulations of THE PRC, 1949-1985), at 657, 661, 664 (finance and trade).

90. Compare the theoretical readjustment in the Soviet Union which accompanied Lenin's New Economic Policy (1921 to 1929), the rise and subsequent purge of the Pashukanis school of economic law in 1937, and the drafting of the "Fundamental Principles of Civil Law of the USSR and the Union Republics," which preceded the economic reforms announced in 1965. See Hazard, Property in the Production Enterprise, in Soviet Legal System 183 (J. Hazard 3d ed. 1977); W. Butler, Soviet Law, Ch. 13 (1983); Hazard, The Abortive Codes of the Pashukanis School, in Codification in the Communist World 145-75 (F. Feldbrugge ed. 1975). Also in Hungary, see G. Eoersi, Fundamental Problems of Socialist Civil Law (1970). In Yugoslavia, see A. Chloros, supra note 41, at Chs. 12, 13.

91. See Hazard, Property in the Production Enterprise, supra note 90, at 177. The Chinese Communist Government officially tolerated private ownership of industry from 1950 until 1965 during which it was transformed into part of the system of socialist ownership, although disruption in the aftermath of economic policies associated with the "Great Leap Forward" had all but destroyed management autonomy in enterprises by the early 1960's. Socialist transformation was accomplished in three broad steps: first, private industry was brought under central economic management; second, private enterprises were converted into joint state-private enterprises; and finally, capitalist shareholders were in effect bought out by payment of fixed interest as returns on their investment. In many cases, it appears, capitalist managers were left in charge of enterprises with a greater degree of management autonomy than has since ever existed.

92. See infra at 818-20.

93. See G. EOERSI, supra note 90 .

94. Two Chinese writers have traced the Soviet influence to a work by A. Venediktov, OWnership in Socialist Countries (1948); see Wang Liming \& Li Shinong, A Discussion of the Question of State Ownership [and] Enterprises Owned by the Whole People, 1 Zhongguo Shenui Kexue (China's Social SCiences) 3 (1986), also reprinted in 3 Fuyin baokan ziliao (FaXue) (Reprints of Newspaper and Journal Materials (Legal Studies)) D41, 65, 86 (1986) (translated into English in Social SCienCes in China, Summer 1987, at 21 ). 
represented by competent state organs or enterprises. This agency theory has since been largely discredited both in China and the Soviet Bloc, but it has left its mark on some contemporary Chinese theorists. ${ }^{95}$

In the Soviet Bloc, the agency theory was gradually displaced by the notion that state organs and enterprises could be made independent subjects of civil law by a segregation of state property based on budgetary allocation. ${ }^{96}$ State property thereby appropriated to state organs and enterprises would be under their "operative management." Thus was born the concept of "operative management," which was defined as the right to possess, use, and dispose of state property according to law and the economic plan. This formula has been incorporated into civil legislation in the Soviet Union and other Eastern Bloc countries. ${ }^{97}$ It was at this stage of theoretical development that China's civil law writers adopted the Soviet theory as their own.

State organs [and] state-run enterprises have an independent right of operative management (jingying guanli quan) over state property according to law; this means:

1. State organs [and] state-run enterprises have the power according to the provisions of state policy, laws, and decrees to control the property they manage within the scope of their functional authority;

2. State organs [and] state-run enterprises can participate in civil intercourse in the capacity of legal persons [and] independently assume property liability to third parties;

3. The content of the right of operation and management is, according to the state's intent, to exercise the powers and functions of possession, use[, and] disposition over state property in order to fulfill the state plan. Ownership of the property is still vested in the state. State organs and state-run enterprises certainly cannot acquire ownership. ${ }^{98}$

The Chinese term "right of operative management" means literally "operation [or "business'] management right" 99 and is clearly based on the same term developed by Soviet theorists and later used in Soviet civil legislation. ${ }^{100}$ The nature of this right as defined in the passage above was reflected in draft legislation on state industrial enterprises in the same

95. See infra at 199, 205-06 and the views of Liu Xiaohai \& Xu Wusheng.

96. See G. EOersi supra note 90 , at 99.

97. See Soviet Legal System, supra note 35; Civil Code of the Russian Soviet Federated Socialist Republic, art. 94 (Gray \& Stults trans. 1965); for the Hungarian Civil Code see G. Eoersi, supra note 90, at 101, and for the relevant provision in the Czechoslovak Code of Economic Law, see Wang \& $\mathrm{Li}$, supra note 94 .

98. Fundamental Problems of Civil Law, supra note 2, at 138-39 (emphasis supplied). The similarities with Soviet theory are evident in extracts from an article titled State Ownership and the Right to Operate and Manage, which appeared in the Soviet journal 3 Faxue (JURISPRUDENCE) (1976), and was translated into Chinese in Waiguo minfa ziliao xuanbian (Selection of Materials on Foreign Civil Law) 272 (1983).

99. Jingying guanli quan. Here, "business" is translated as "operation" to make clear that it is a right intended to be enjoyed by administrative organs as well as production enterprises.

100. Wang \& $\mathrm{Li}$, supra note 94. See also Fundamental. Principles of Civil Legislation of the USSR and Union Republics, supra note 35 (art. 21); Civil Code of the Russian Soviet Federated Socialist REPUBLIC, supra note 97 (art. 94). The Chinese translation of the Soviet term is usually the same, jingying guanli, but has also been translated as "actual management"(shiji guanli). See Sulian minfa gangyao he minshi susong gangyao (Fundamental Principles of Civil legislation and Civil Procedure of the USSR and Union Republics) 12 (Law Research Institute Chinese Academy of Social Sciences trans. 1963). 
period. ${ }^{101}$ How far these restrictive theories determined the basis for Stalinist-style industrial management in China before economic reforms began in the secondary and tertiary sector in 1979 is unclear, but the shortcomings of this management system are now well documented. ${ }^{102}$

First, state enterprises had little effective control over their working capital. Capital assets were allocated to enterprises gratuitously and could be reallocated without redress. ${ }^{103}$ Enterprises contributed to depreciation funds for the renewal of capital assets, but these funds were also controlled by the state. Moreover, enterprises paid a large part of their net profits over to the state. Therefore, an enterprise had no means to acquire new working capital other than to negotiate the bureaucratic hierarchy and apply for an investment allocation which might not be approved in a reasonable time, if at all. As a result, most enterprises jealously guarded even their idle capital assets lest they be reallocated to another enterprise. This caused vast waste and inefficiency.

Second, enterprises operated under a strict production plan. Under the unified system of supply and marketing, goods were produced with materials supplied according to a plan and marketed according to another plan. Supply and marketing took place by means of so-called economic contracts, but the administrative constraints on the bargaining power of the parties were so severe that it was doubtful whether these agreements could be called contracts at all. ${ }^{104}$ Moreover, all this took place under rigid, and frequently irrational, price control. Finally, enterprise production management was divorced from economic performance because there were neither material incentives for good management nor disincentives for poor management; the state was liable for any enterprise losses.

The problems China's reformers are trying to solve today are the same ones Hungary faced in the 1960's. ${ }^{105}$ Hungarian theorists sought to replace the concept of the "right of operative management" with the right of economic autonomy of the enterprise. The latter was meant to define in much more generous terms the relationship of an enterprise to its state-allocated property. One Hungarian theorist wrote:

The relationship between the independent assets of the enterprises and their economic autonomy is the same as between property and ownership. In this consists the

101. "[T]he state industrial enterprise is also an independent production and business unit with the right to keep independent economic accounts according to state regulations. It takes full responsibility for fixed and floating assets given to it by the state and may not sell them off or transfer them without the approval of state administrative organs. It has the right to use fixed and floating assets given to it by the state to carry on production according to the state plan." State Industrial Enterprises Work Regulations (Draft) 1961 (art. 1), in ZHONGHUA RENMIN GONGHEGUO GONGYE QIYE FAGUI xuanbian (Selection of Legislation of the PRC on Industrial Enterprises) 46 (1981).

102. See, e.g., Xue M., China's Socialist Economy (2d ed. 1986) Ch. 8; Decision of the CCCPC on Reform of the Economic Structure, China Daily, Oct. 23, 1984, at 1.

103. Tong R. 1, supra note 22, at 139.

104. Pfeffer, The Institution of Contracts in the Chinese People's Republic (pts. 1 \& 2), 14 CHINA Q 153 (1963), 15 CHINA Q. 115 (1963).

105. G. EOERSI, supra note 90 , at 101 . 
subjective civil-law status of an enterprise. In reality, the enterprise may act in the same way as an owner. . . 106

The idea that state-owned enterprises have the "right to operative management autonomy" (jingying guanli zizhu quan) was adopted in Chinese legislation for the first time in 1979.107 It was entrenched in the 1982 Constitution, ${ }^{108}$ and it is still accepted doctrine. ${ }^{109}$

In the first half of this decade there was no clear theoretical basis for the legislative innovations ${ }^{110}$ which over time have given state enterprises more power over their fixed and floating assets. While Hungarian theorists introduced the concept of enterprise autonomy to replace the "operative management right," in China, theorists and legislators have continued to use both concepts, sometimes combining them. ${ }^{11}$ Yet, Chinese theoretical works have not clearly defined the relationship between these two concepts, and not all theorists agree that they are synonymous. ${ }^{112}$

There is still debate in theoretical works as there was in the drafting of the General Principles itself about such questions as: Is enterprise autonomy as such a legal right at all? Or is it rather a goal which economic reforms hope to achieve in the state industrial sector? ${ }^{13}$ And what legal means are needed to achieve this goal?

\section{B. Theoretical Innovation}

In surveying more than thirty recent Chinese theoretical discussions on property rights in the state enterprise, I have identified approximately ten different schools of thought. ${ }^{114}$ Rather than embark on a turgid discussion of

106. Id. (emphasis added).

107. See Certain Regulations Concerning the Expansion of State Industrial Operative Management Autonomy, in Collection of Laws and Regulations of the PRC 249 (1979).

108. Art. 16 .

109. See State Council Provisional Regulations Concerning Further Expansion of State Industrial Enterprise Autonomy, in Collection of Laws and Regulations of the PRC 479 (1984).

110. See Wang L. \& Liu Z., supra note 29.

111. See supra note 110. Some theorists have said the two terms mean the same thing, see infra at 204.

112. Cf. infra at 204. The right to autonomy has also been applied to the collective economy, see State Council Certain Provisional Policy Regulations Concerning the Collective Economy in Towns and Cities, in Collection of Laws and Regulations of THE PRC 517 (1983) (especially art. 9).

113. "To sum up, the [state] enterprise should really become a relatively independent economic entity, a socialist commodity producer and business entity carrying on business autonomously [and] being responsible for its own profits and losses ...." (emphasis added). Decision of the Central Committee of the Communist Party of China on Reform of the Economic Structure, in 1 GONGYe QIYE GuANLI WENJIAN HUIBIAN (Collection of Documents on Management of Industrial Enterprises) 26 (Department of Industrial Economics Chinese People's University ed. 1985). (The widely circulated English (ranslation, see supra note 102 , omitted the words emphasized.)

114. These are (1) the enterprise is merely an agent of the state which is the owner of state property, including the enterprise itself; (2) the state has absolute ownership in state property but the enterprise also enjoys ownership of a relative kind; (3) the state has ownership of state property, and the enterprise has ownership of the property of a legal person; (4) the state owns state property over which the enterprise has a defined right of possession; (5) the state owns state property, and the enterprise has the right of operative management over it; (6) the state owns state property, and the enterprise has the rights of possession, use, benefit, and a limited right of disposal; (7) the state owns state property, and the enterprise has commodity ownership, viz., ownership in the product of stateowned means of production and labor; (8) the state has ultimate control or pure ownership of state 
every school of thought, however, I will divide the ten schools of thought into three general theses. The theses are: (1) that the right of operative management is a product of administrative or economic law; (2) that enterprise autonomy can only be achieved by creating a new property right; and (3) that both the state and state enterprise enjoy ownership rights. No doubt the Chinese authors in this issue as elsewhere will all feel aggrieved by this system of classification, but its purpose is to demonstrate the way in which most theorists have attempted to preserve state ownership while equipping the state enterprise with the greatest possible business autonomy. I shall also endeavor to point out the major variations and conflicts within each class of theory.

When working within a rigidly defined ideological framework such as exists in China, theorists are most frequently engaged in controversy about the means to an end rather than the end in itself. It should therefore be no surprise that in this legal controversy all theorists start from the same premise: Within China's system of ownership by the whole people, the state is ultimately the owner of public property; but within that same system the state enterprise shall enjoy autonomy to engage in economic activities. It must therefore be equipped with defined rights over the property allocated to it by the state or generated by its own economic activities.

1. The Theory of Operative Management Rights. As explained above, the right of operative management is a Soviet invention intended to apply both to state administrative organs and institutions as well as to enterprises. Today, among Chinese and Eastern Bloc theorists, it is still controversial whether this right is a creature of civil, economic, or administrative law. The arguments put forward would be all too familiar to a Soviet or Hungarian jurist. The Chinese views can be boiled down to three basic positions.

First, some economic law theorists ${ }^{115}$ argue that the right of operative management is a product of the integration of state administrative power and

property, while the enterprise enjoys rights of possession, use, benefit, and disposition; (9) the enterprise leases state property from the state; (10) the enterprise enjoys a real right in the property owned by the state: the right to operate.

115. In China, legal theory concerning economic relations is divided into two broad schools of thought: economic law theory and civil law theory. In its extreme form, the first school of thought denies the application of civil law principles to any production activities pursuant to state economic planning. Such economic activities are regulated by economic law principles, which are a synthesis of horizontal and vertical legal relations taking the place of civil law and administrative law. The scope of civil law is thus limited to those economic relations, usually consumption rather than production, outside the state plan.

The civil law school of thought, however, maintains the view that economic relations in a capitalist economy and a socialist economy are both commodity relations and are therefore governed by property relations defined by civil law. The civil law school regards economic law merely as a study of those occasions when adminstrative law affects the application of civil law.

The tension between these two schools of thought was a major factor delaying the promulgation of a code of civil law in China and partially explains why only a set of general principles was ultimately adopted. The debate was inherited from early Soviet jurisprudence, and it is still a tense one in China today. On the Soviet origins of the economic law school, see Hazard, The Abortive Codes of the Pashukanis School, supra note 90. For an introduction to the relationship between civil and economic law in China, see Kato, Civil and Economic Law in the PRC, 30 Aм. J. Comp. L. 429 (1982). 
the powers and functions of ownership in public property enjoyed by the state. For example, a glance at any Chinese textbook on economic law will reveal that the operative management right is a composite expression used to describe the "material foundation" for the rights and duties of a state organ or enterprise to complete the state plan. ${ }^{116}$ The influence of Soviet theory on this view is clear. ${ }^{117}$ One example is an article by Liu Xiaohai in a recently published collection of essays on economic law:

The right of operative management ... is not a civil right. ... [It] has been suggested with ample consideration given to the needs of the system of state ownership and economic planning [and] it does not rigidly adhere to traditional civil law concepts ... . [I]n a socialist system the relationship between the state and state enterprise is that betweeen owner and branch organ, united within the system of state ownership ...118

Accordingly, Liu defines the operative management right as "the responsibility effectively to exercise the rights of possession, use, and disposition over public property as intended and mandated by the state." 119 In his view, it is not an independent property right at all. ${ }^{120}$ He believes the problem of excessive administrative interference in enterprise activities arises not from want of a definition of the right of operative management but from the failure of administrative organs to respect that right. The fact that collective enterprises enjoy ownership in their own property, Liu says, has not rendered them immune to administrative interference. ${ }^{121}$ His pragmatic view may well represent the feelings of the silent majority among China's reformers who seek to cast off the yoke of administrative interference not by inventing new theories but by promoting entrepreneurship. ${ }^{122}$

116. Zhongguo jingjifa Jiaocheng (Textbook of China's Economic LaW) 75 (Economic Law Teaching and Research Section Law Dept., Chinese People's Univ. ed. 1985). This, civil law theorists would surely say, is merely an obfuscation of a property right in civil law.

117. Wang \& $\mathrm{Li}$, supra note 94 (quoting $\mathrm{A}$. VenedikTov).

118. Liu Xiaohai, $A$ Discussion of the Legal Nature of the Property Rights of Our Country's State Enterprises, in JiNGJiFa LUNWEN XUan (Selection of Essays on Economic Law) 157, 164 (Jin S. \& Bing Y. eds. 1986). Also published under same title in 1 Fudan faxue (Fudan Legal Studies) 139 (Fudan Univ. Law Department eds. 1986).

119. Id. at 165. This reproduces the Soviet view: "A subject which operates and manages has the power and ability to possess, use, and dispose of state property but at the same time these rights are also obligations it owes to the state. For example, a state organization cannot but possess, use, and dispose of state property; it cannot but treat state property as part of its property for the purposes of assuming liabilities; it cannot but use state property in the process of production or using state property according to state regulations or other measures; it cannot but dispose of state property according to state regulations." Selection of Materials on Foreign Civil Law, supra note 98, at 278.

120. Id. at 163. This view is shared by some civil law theorists: "[T] [state] enterprise is a product of state administrative mandate . . ." WANG L. \& Guo F., ThE Securitization of State-Owned Enterprises and State Ownership 5 (emphasis added). The authors kindly supplied me with the manuscript of this article, but thus far only a truncated version of their views has been published sub nom. The Securitization of Stale-Owned Enterprises and the Evolution of State Ownership, 6 Zhongguo QIngnian Jingji daobao (China Youth Econ. Trib.) 38 (1986). See also Jiang Ping, infra note 169 and accompanying text at 41. On the meaning of securitization (gufenhua) in China's enterprise ownership reform, see Chao \& Yang, infra note 180 and accompanying text.

121. Liu, supra note 118 , at 163.

122. See Thiel \& Chao, Enterpreneurship in China: Coping in a Socialist Market Economy, in J. KAO, Global ENTERPRENEURShip (forthcoming). 
Second, other theorists claim the right of operative management is derived from ownership itself. ${ }^{123}$ This might be called an early civil law theory because unlike economic law theorists, Chinese civil law writers until recently have claimed that the right of operative management was a civil law right derived from the state's ownership of property. It is no coincidence that the fourth draft of the civil code was circulated at the same time new editions of civil law treatises were published, the first to appear since the resumption of legal scholarship in post-Mao China. The concept of the right of operative management can be traced to both the drafting of the civil code and the textbooks which accompanied it.

In its first edition, China's standard work on civil law acknowledged that a number of new theories had developed to explain the property relationships between the state and the state enterprise. The authors rejected all of these theories, however, because those theories tended to deny that the state was the one and only subject of state ownership. Instead, they explained the property rights of the state enterprise in the language that was used in the 1950 's, although the term "property management right" (caichan guanli quan) was substituted for "operative management right." 124 They emphasized that the state enterprise's right to possess, use, and dispose of state property derived from a state mandate and that its exercise could not exceed the scope of this mandate or violate state plans. Furthermore, the state could use administrative means to amend the plan and thereby adjust the enterprise's organization or production activities. Subject to these qualifications, the enterprise would enjoy relatively independent autonomy of operation and management. ${ }^{125}$

What is "relatively independent autonomy"? It is hard to imagine what autonomy is left after being subject to all these limitations. Nevertheless, theory continued to exert influence on the legislative drafting. Provisions in the 1982 draft of the civil code are reminiscent of the early Soviet inspired theory.

The People's Republic of China is the sole owner of all state property.

The state mandates state organs, enterprises[, and] institutions with state property and provides the scope for the exercise of their right of operative management. ${ }^{126}$

The first principle is still unquestionably official theory, but, as discussed below, new theories of divided ownership may effectively erode the state's traditionally unchallenged status. The second principle is further defined by another provision:

123. Cf. Wang \& Li, supra note 94 , at 40 (quoting the view of Hungarian jurist G. Eoersi, that the right of management is itself one of the powers and functions of ownership).

124. Tong R. 1, supra note 22, at 134-42. See also WANG Z., supra note 53, at 142.

125. Tong R. 2, supra note 22, at 135-36. The second edition stresses macroeconomic controls as an aspect of state ownership. See also Cheng Shou, A Tentative Discussion of the Legal Nature of Our Country's State Industrial Enterprises' Operative Management Right in State Property, in SELECTION of EsSays on ECONOMIC LAW, supra note 118 , at 65.

126. Draft art. 48 (emphasis added). 
State organs, state-run enterprises, and institutions have the right within the scope of the state's mandate to exercise possession, use, and disposition over state property under their operative management. ${ }^{127}$

This is the classic Soviet formulation. ${ }^{28}$ However, from the drafts of the General Principles, it seems that since the fourth draft of the civil code was circulated in 1982, many civil law theorists must have reassessed the suitability of the kind of thinking behind the traditional theory of enterprise property rights as expressed by Liu Xiaohai above.

More recently, some civil law theorists rejected both of these views and argued that operative management was not a civil right at all. ${ }^{129}$ The next step, then, was the invention of new property rights to take the place of operative management.

2. Theories About New Property Rights. Most public discussion about property rights in the state enterprise has appeared since 1985, but it would be inaccurate to say that no new ideas were published before the drafting of the General Principles was imminent or in progress. One such early work was published in the influential bimonthly Studies in Law (Faxue yangiu) in 1980.130 Its three authors are from the Chinese University of Politics and Law, and at least one of them later participated in drafting the General Principles. ${ }^{131}$

These authors argued that the theory of operative management rights could not explain the relationship between the state and state enterprises. The state is the owner of state property but does not directly participate in civil activities. Enterprises, on the other hand, participate in civil activities but are not owners. This contradiction gives rise to a situation where both the state and the enterprise must have property rights, but the enterprise's operative management right is not a property right; it is a liability. ${ }^{132}$ The enterprise owes the state a duty to operate and manage its property as directed by the state. All property rights, according to this theory, remain in the state. Management, as used here, means property management in the civil law sense, but the term is too easily confused with management in the administrative sense. The right of management, argue the authors, is more an economic concept than a legal one, and therefore the exact attributes of this right are not clear.

The explanation for this duality of property rights, they argue, is that the state has ownership of the means of production and the enterprise has the right to possess the means of production. Although the right to possession is a derivative of ownership it is a kind of independent right in things. It is the property right enjoyed by the enterprise. Ownership is the material foundation for the state's ultimate control over the means of production and the right of possession is the direct basis for the

127. Draft art. 82.

128. Cf. Soviet provisions (supra note 97) with the above draft provisions.

129. Wang \& $\mathrm{Li}$, supra note 94.

130. Jiang Ping, Kang Deguan \& Tian Jianhua, The Property Relations Between the State and the Staterun Enterprise Should be the Relationship Between Owner and Possessor, 4 Studies in Law 6 (1980).

131. Prof. Jiang Ping is from the Civil Law Teaching and Research Section of the Law Department.

132. Jiang, Kang \& Tian, supra note 130 , at 7. 
enterprise's ability to do business relatively independently and enjoy its own independent benefits. ${ }^{133}$

They trace this division between rights of ownership and possession in economic activities back to Marx's theories of surplus value. ${ }^{134}$ Marx showed that, under the system of feudal land tenure, the producer was not the owner but merely had a right of possession in the land and by this means the owner alienated the value of the producer's (possessor's) surplus labor. Extraordinary as it may seem for latter-day Marxists to borrow from an analysis of a feudal system of rights, the authors argue that such a division is equally applicable to the relationship between the state and state enterprise in China today.

This view has been criticized by economic law theorists because the use of the concept of possession conceals the new meaning of property rights in the state enterprise. They cite, for example, the duty the enterprise owes to the state to use its property effectively within the scope defined by the state. ${ }^{135}$ In fact, the authors redefined possession and distinguished it from the traditional civil law concept:

But here, what is called the right of possession means that subject to the owner (the state) reserving the ultimate right of disposition, the possessor (the enterprise) enjoys ample control over the owner's property. ${ }^{136}$

"Ample control over the owner's property," however, includes possession, use, and disposition for value. ${ }^{197}$ This analysis has also been taken to task by civil law theorists because, it is argued, there is no basis in the civil law for including any power of disposition in the right of possession. ${ }^{138}$ Thus, it would seem that this early attempt to rethink the nature of the property relations between state and enterprise floundered because the concepts it used were not acceptable to either economic or civil law schools of thought.

i. Usufruct. The same fate awaited another theory presented in Studies in Law two years later. ${ }^{399} \mathrm{Li}$ Kaiguo, from the Law Department at the Southwestern Institute of Politics and Law, clearly meant to attack the view that state enterprise property rights could be explained in terms of a theory of divided ownership. At that time such a view was only the subject of internal debate, but $\mathrm{Li}$ intended to nip it in the bud by accusing its proponents of offending the sacred principle that state enterprise property belongs to the

133. Id. (emphasis added).

134. K. MarX, Theotics of Surplus Value, in 4 Capital.

135. Liu, supra note 118, at 160-61. See also supra note 119 and accompanying text

136. Jiang, Kang \& Tian, supra note 130 , at 7 . The authors continued: "Therefore, the right of possession is a type of relative ownership right or indirect ownership right." Unfortunately, this conclusion was not further developed. However, it clearly shows the seeds of the theory of divided ownership rights examined below.

137. Id.

138. Wang Liming, Problems Concerning Possession, the Right of Possession and Ownership, I Faxue PInglun (Law Rev.) 15 (1986) (Journal of the Law Department, Wuhan University). See also Wang \& Liu, supra note 110.

139. Li Kaiguo, A Discussion of the Nature of the Property Rights of the State Enterprise, 2 Faxue yanju (Studies In Law) 34 (1982). 
state as the sole representative of the whole people. ${ }^{140}$ To recognize that the state enterprise has ownership in its property would be to say that state enterprises and collective enterprises are the same. This would seriously weaken, if not destroy, the effect of state planning on the economy. ${ }^{141}$

Instead, Li sought to explain enterprise property rights in terms of usufruct. Usufruct (yongyi quan), he argued with reference to Roman, French, and German civil law, is an independent right in things (wuquan), such as that enjoyed by the enterprise in state property; and it is only out of habit that it is continually called a "right to operate" (jingying quan). ${ }^{142}$ This is the earliest usage I have found of the term now used in article 82 of the General Principles. ${ }^{143} \mathrm{Li}$ did not care what this right was called but was concerned that its legal nature be correctly defined. As owner, the state can set production goals, collect depreciation fees, recover the assets of an enterprise after its winding up, and generally engage in planning and supervision of its economic activities. As usufructary, the enterprise can possess, use, and dispose of state property within production plans, but disposition of fixed assets must first be approved by the state. The usufruct also comes with the duty to protect state property. The advantages of usufruct, Li argued, was that it gave the state enterprise independence in economic activities while holding it responsible for state property and protecting the system of public ownership. ${ }^{144}$

In many respects Li's definition of this enterprise usufruct differs little from the concept of enterprise possession developed by the authors discussed above or from the operative management right concept. In terms of the application of the civil law concept of usufruct to a novel set of circumstances, however, $\mathrm{Li}$ was original. Such an application, however, is fraught with theoretical difficulties. Usufruct does not usually entitle the usufructary to dispose of the subject matter, an essential attribute of the enterprise's power over property entrusted to it by the state. ${ }^{145}$ Although Roman law, and in its wake the $\mathrm{BGB}$, developed an exception to this rule with respect to fungibles, the result was that property disposed of by the usufructary would become his property and he would be liable to compensate the original owner for its value. ${ }^{146}$ Applied to the enterprise usufruct, this would mean that when using or disposing of fungible state property the enterprise would become the owner and pass title as owner. $\mathrm{Li}$, of course, would reject this possibility but without any theoretical justification. ${ }^{147}$

140. Id. at 35 .

141. Id. (This is precisely the argument used by Soviet theorists cf. supra note 98, at 275.) $\mathrm{Li}$ Kaiguo also said that it was no answer to say that, without sole ownership, the state had macroeconomic controls over the economy.

142. Id. at 36. Also, Li specifically refers to provisions in the 1922 RSFSR Civil Code (Ch. 2) and the Civil Code of the Democratic Republic of Germany which create a usufruct to use state land and buildings (Bk. 4).

143. Cf. infra at 205.

144. Id. at $37-38$.

145. Compare supra note 119. It is for this reason Liu Xiaohai rejects Li's view.

146. Cf. supra at 191 .

147. Li, supra note 139 , at 36. See also Wang, supra note 110 . for criticisms of this view. 
ii. Right to autonomy. As discussed above, in earlier legislation there were traces of the Hungarian concept that enterprise autonomy is a property right created by a budgetary allocation. This has been referred to as "the right to operative management autonomy" 148 or simply "the right to autonomy." 149 Soviet theorists treated autonomy as an outgrowth of the right of operative management in state property, not as a right in itself. ${ }^{150}$ Thus, Chinese theorists must have been asking themselves whether operative management autonomy was a civil right at all. As will be seen below, there is evidence to show that some theorists thought it was, and this had a direct effect on the drafting process. ${ }^{151}$

Sun Xiaoping asserted that the operative management right and the right to operative management autonomy as used in the 1982 Constitution were two completely different concepts. ${ }^{152}$ He treated operative management as an administrative right subject to the will of the state. However, he said that the right to autonomy was a property right because it gave the enterprise control over public property according to its own will and not that of the state. ${ }^{153} \mathrm{Jin}$ Tianxing, on the other hand, argued that the right of operative management and the right to operative management autonomy were one and the same; the latter was merely China's constitutional expression of the former. ${ }^{154}$ In yet another article, two scholars from the Chinese People's University argued that the precise definition of property rights by the civil law was the key to enterprise autonomy, thus suggesting that autonomy was an end in itself rather than the means to an end. ${ }^{155}$ Still, it remained unclear whether enterprise autonomy was a right and, if so, what its legal nature was.

Evidence of this controversy had emerged already in the "Draft for Comments," 156 and it came to a head in the first major revised draft of the General Principles presented to the Thirteenth Session of the Standing

148. Jingying guanli zizhu quan, supra note 107, and accompanying text.

149. Zizhu quan, supra note 109.

150. 3 FAXUE (JURISPRUDENCE), supra note 98, at 275.

151. The evidence first became visible in the "Draft for Comments," to be discussed.

152. 4 FAXUE JIKAN (LAW Q.) 29 (1985) (Journal of the Southwestern Institute of Politics and Law).

153. Id. Further support for this position may be found in an article by Lu Zhengping, but he has since adopted a radically different theory on enterprise property. See Preliminary Exploration of the Features of the State Enterprise Legal Person, in SELECTION OF ESSAyS ON ECONOMic Law, supra note 118, at $167,170$.

154. A Discussion of Ownership of State Property, 2 Anhui daxue xuebao (Anhui Univ. Rev.) 74 (1986).

155. Tong Rou \& Fang Liufang, Civil Law and Enterprise Autonomy, Guangming Daily, June 11, 1986 , at 3 .

156. Other than a general provision on civil rights which included the "right to operate," this draft did not make a general statement on the state enterprise's property rights. In draft article 33, however, it was provided that a state enterprise would bear civil liability from property under its operative management. Opposition to this draft provision is clear from a drafting note: "Another view is that after a legal person has gone bankrupt the question of what liability the investor bears is quite complicated, e.g., what liability should the state bear for the debts of a state enterprise ... It is very hard to make a clear provision here. It is suggested that this article be omitted. In the future it can be provided in company law, bankruptcy, and other laws." Draft for Comments (unpubl.); see supra notes 20,21 . 
Committee of the Sixth National People's Conference. ${ }^{157}$ In introducing this draft, Wang Hanbin said that the provisions on property rights were drafted "to suit the needs of economic reform, according to the principle that ownership, right to operate, and right to use can properly be separated [from one another]." 158 He explained the need to define and protect enterprise autonomy in the following terms:

Now, there are some superior leading organs which arbitrarily interfere with the autonomy of state enterprises in respect to personnel, property, materials, supply, production, and marketing as provided by the state [by] wilfully transferring or apportioning state enterprises' assets, material, and so on. ${ }^{159}$

Draft article 57 was accordingly formulated:

State enterprises enjoy the right of operational autonomy (jingying zizhu quan), that is, in respect to property given to the enterprise to operate and manage [they] enjoy the rights to possession, use, lawfully obtained benefits, and disposition within the scope mandated by the state.

The state protects the state enterprises' right to operational autonomy; no organization or individual shall unlawfully interfere.

Here was the "right of operational autonomy" about to be elevated to the status of a property right in civil law.

iii. Right to operate. The textbook writers could not have been pleased about this. The second edition of the standard treatise on civil law had just been completed. ${ }^{160}$ Extensive revisions had been made to the text concerning state enterprise property rights. Following the lead of the Chinese Communist Party's Decision on Economic Reform the previous year, ${ }^{161}$ the authors had adopted the view that while the state is the only owner of property which belongs to the whole people, the state enterprise enjoys a right to operate (jingying quan) state property. ${ }^{162}$

Although the authors did not treat the right to operate unequivocally as a property right, this intention seems clear from a discussion in the context of the property relationship between state and state enterprise. ${ }^{163}$ Moreover, the authors now stressed that the state could use macroeconomic controls, not merely administrative means, to exercise its ownership rights. ${ }^{164}$ This is an important change in emphasis which tends to show their intention to separate clearly state and enterprise property rights and thereby realize the object of operative management autonomy quoted from the Constitution.

157. This draft is also unpublished. For its place in the sequence of drafting evolution see Epstein, supra note 20.

158. China Legal News, supra note 48.

159. Id. .

160. Tong R. 2, supra note 22. The editorial foreword to the work is dated October, 1985.

161. It was here that the term "right of operation" was first used in an official document. "As Marxist theory and the practice of socialism have shown, ownership can be duly separated from the right to operate." XUE M., supra note 102, at 2.

162. Tong R. 2, supra note 22, at 163.

163. Id. at $162-166$.

164. Id. at 160 . 
After the right to operate had appeared in a gloss with other property rights in the first draft of the General Principles, ${ }^{165}$ it was replaced by operational autonomy. ${ }^{166}$ A by-product of the tension between supporters of the two theoretical approaches was that the question of property rights in the state enterprise and its relation to state ownership was conspicuously absent from the next draft, which was produced by the Thirteenth Standing Committee and the meeting of 180 experts called by Peng Zhen. ${ }^{167}$ The issue was then settled in the final draft presented to the Fourth Session of the Sixth National People's Congress. It contained a provision couched in substantially the same terms as article 82 :

The state-run (guoying) enterprise's enjoyment according to law of the right to operate property handed it (jiao you ta) by the state for operation and management is protected by law.

There were two obvious changes made in article 82. First, the final draft substituted state-owned (quanmin suoyou) for state-run enterprise to make the provision consistent with the language used in chapter 3, section 2. Second, the word "handed" (jiaoyou) was replaced with the word "conferred" (shouyu) probably to make clear that the state property is transferred to the state enterprise with appropriate powers and functions.

It is not clear who first had the idea of a "right to operate" or when the term was first invented.168 It appears to have been created simply by dropping the term "management" from the original Soviet term. At least two theorists used the terms "right to operate" and "right of operative management" interchangeably. ${ }^{169}$ Another has said that the two are not interchangeable. ${ }^{170}$ The consensus appears to be that the right to operate is a property right of a lesser degree than ownership; however, different theorists have used different theoretical tools to describe it.

Most interesting is the idea that the right to operate is a new kind of right in things. This view is expressed by a number of writers, but they nevertheless come to different conclusions about the scope of the powers and functions enjoyed by the enterprise and the state's ability to interfere. Civil law scholars Tong Rou and Zhou Wei suggest that the right to operate is derived from state ownership for the purpose of realizing the economic potential of state property. ${ }^{171}$ It is, however, neither a single attribute of

165. See supra note 156.

166. See supra at 205.

167. See Epstein, supra note 20.

168. The term seems to have been used by theorists as early as 1982; see supra note 139 and accompanying text.

169. Jiang P., supra note 37 , at 166 ; Li \& Qian, supra note 50.

170. $\mathrm{Xu}$ Wusheng argues that the right to operate represents the enterprise's civil law rights over its property in horizontal relations, while operative management is a comprehensive right including internal vertical relations such as labor management. Probing the Properly Rights of the State-Owned Enterprise Legal Person, 2 Studies in LaW 46 (1986).

171. Tong \& Zhou, A Discussion of the State-Run Enterprise's Right to Operate, 3 STudies In Law 12 (1986). Tong Rou is from the Civil Law Teaching and Research Section in the Law Department of the Chinese People's University and is the chief editor of the standard treatise on Chinese civil law (see supra note 22); Zhou Wei is from the Department of Law at Sichuan University. 
ownership nor a form of relative ownership; it is a right in things which gives the enterprise exclusive control over the property it operates. ${ }^{172}$ This means that, unlike administrative powers, no two subjects can have the right to operate the same property. Finally, and most importantly, it means that once state property has been transferred to an enterprise it cannot be acquired or reallocated by the state without compensation. ${ }^{173}$

Strikingly, two scholars from Peking University's Law Faculty have reached almost the opposite conclusion about its scope. While agreeing that the right to operate (or the right of operative management) is a new type of right in things (including possession, use, benefits, and disposition), they argue that because the right to operate is derived from state ownership, it is wholly determined by the state as dictated by planning and production requirements. ${ }^{174}$ This means that the scope of the right varies not only according to the property transferred to the enterprise but also according to the type of its economic activity. The more important the enterprise's activities to the state plan, in effect, the narrower will be the scope of its right to operate state property. ${ }^{175}$ It also means that the state has the power to allocate fixed assets without compensation. ${ }^{176}$

Every view taken sets out to establish a basis for some degree of state enterprise immunity from adminstrative interference. Tong Rou and Zhou Wei put their position most clearly, but, as is also true for others, the traditional theoretical tools fail them. If the right to operate state property is a right less than ownership in a thing to the exclusion of third parties, there seems to be no explanation for the enterprise's ability to exclude the owner of the property itself, i.e., the state. Moreover, if state administrative organs are the arms and legs by which the state manages the economy, what theoretical (let alone practical) justification is there to exclude their acts on behalf of the state to dispose of or otherwise deal with state property? Without this degree of immunity from interference, however, enterprise autonomy is meaningless. For that very reason, some civil law theorists have already abandoned the concept of a right to operate and have sought some firmer theoretical foundation for enterprise autonomy."177 In the meantime the "right to operate" remains the only officially recognized property right in the state enterprise, and it is on this basis that further legislation on enterprise reform is being drafted. ${ }^{178}$

172. Id. at 17

173. Id. See also Lu Zhengping, Preliminary Investigation into the Features of Enterprises Ouned by the Whole People, in Selection of Essays on Economic Law, supra note 118, at 167, 172.

174. Li \& Qian, A Discussion of the State-Owned Enterprise's Right of Operative Management, 2 STUdies IN LAW 32, 34 (1987).

175. Id. at 36 .

176. Id. at 37. For a similar view see also Ding Jimin, Right to Operate and Ownership, I Studies IN LAW 12 (1987).

177. See infra Part VI.

178. E.g., State-Run Enterprise Property Management Regulations, Sept. 1986 (draft for revision). Art. 4 provides, in language reminiscent of the Soviet civil codes: "The ownership of the property of the state-run enterprise is vested in the state; the enterprise has the right to possess, use, benefit, and dispose of [that property] within the scope provided by law and regulations." 
iv. Ownership rights. In August 1986, the Propaganda Department of the Shanghai Branch of the Chinese Communist Party organized a meeting to discuss the question of reforming the system of ownership in the means of production. From a record of that meeting published in the People's Daily, it is clear that the single most controversial issue was how to reform the system of state ownership in the secondary and tertiary sectors. ${ }^{179}$ Three possible avenues for reform were identified, but it appears no consensus was reached. First, it was suggested that the existing system could be further improved, for example, by continuing the policy of leasing and contracting out the management of small state enterprises. The meeting concluded, however, that the major difficulty with this scheme was finding a mechanism to ensure enterprise autonomy. Second, it was suggested that state ownership could be converted into enterprise ownership. The problem here was finding a way to use macroeconomic controls to ensure adherence to the concept of a planned commodity economy. Finally, the third scheme was to securitize (gufenhua) state enterprises in such a way that they would become a cooperative venture between the state, the enterprise, and its workers. The problem here is how to define the roles of these three different subjects. China has shown a fascination for Western corporations and securities law. However, in spite of legislative innovation it still lacks a solid theoretical foundation for securitization of the state-owned sector.

The radical proposal for converting state ownership into enterprise ownership was thus brought out into the open. Almost as soon as vigorous theoretical debate started, ${ }^{180}$ however, two new regional laws were adopted to allow state, collective, and foreign-owned enterprises to issue both shares and bonds to the public. ${ }^{181}$ Technically, issuing shares and carving up public ownership between the state and enterprises are two separate issues. Securitization has been justified, like leasing and contract management, as a means of separating the right to operate from state ownership and the power of intervention. ${ }^{182}$ However, many theoretical problems about the property relationships between shareholders and the enterprise remain.

179. Shang Xuanli, Renmin ribao (People's Daily), Sept. 1, 1986, at 5.

180. See Li Yining, A Vision of Ownership Reform in Our Country, People's Daily, Sept. 26, 1986 (Li advocated the securitization of large and medium-sized state enterprises.). See also Chao \& Yang, The Reform of the Chinese System of Enterprise Ownership, 1987 STAN. J. INT'L. L. 365.

181. Xiamen City Trial Measures for the Administration of Enterprise Shares and Bonds, Sept. 1, 1986, China Econ. News, Nov. 24, 1986; Guangdong Province Provisional Measures for the Administration of Shares and Bonds, Oct. 10, 1986, China Econ. News, Nov. 24, 1986.

182. See, e.g., Trial Scheme for the System of Enterprise Share Joint-Ownership (draft for comments) produced by a meeting of political, theoretical, and industrial organizations in Sichuan Province, which provides that the property of an enterprise may be owned jointly by the state, the collective of workers in the enterprise, and individual workers as defined by shares [art. 3] and that the right to operate this property will be vested in the organ representing the workers' collective (collective here means the unity of workers in one enterprise). 6 JINGJITIZHI GaIGE TANSUO (EXPLORATION INTO ECONOMIC REFORM) 10 (1986), reprinted in I FUYIN BAOKAN ZILIAO (JINGJIIFA) (REPRINTS OF NEWSPAPER and Journal Materials (Economic Law)) D411, 73 (1987). See also Li Jingtang, The Share System 1s An Important Form for Separating the Right to Operate from State Ownership, 2 L. REv. 15 (1987); Qiang Li, The Share System and Enterprise Vitality, I Xibei zhengfa xuevuan xuebao (Nw. Inst. Pol. \& L. Rev.) 16 (1987), reprinted id. at 63 . 
Without a sound theoretical basis (not to mention macroeconomic measures) for introducing these new laws, it should not be surprising that the ability of state enterprises to issue shares to the public was short-lived. ${ }^{183}$ In the meantime, legal theorists went back to the drawing board to invent new theories to explain and justify a system of public ownership divided between the state and state enterprises.

Two new schools of thought later crystallized from a meeting of legal theorists organized by the Law Institute in the Chinese Academy of Social Sciences. ${ }^{184}$ The most radical view advocated abandoning the traditional system of state ownership and replacing it with a system where enterprises enjoy the independent ownership rights of a legal person, in effect, by transforming state enterprises into collective enterprises. ${ }^{185}$ Some published essays come close to this point of view, ${ }^{186}$ but none go so far as to advocate re-collectivization, which is inimical to the idea that the expansion of state ownership represents progress in the history of China's economy since 1949 .

The second school of thought advocated the division of ownership into absolute ownership, reserved to the state, and relative ownership (or commodity ownership) enjoyed by state enterprises. There are many proponents of this conceptually difficult and nebulous theory. One early and pragmatic exposition was given by a researcher at the Law Institute itself. Liang Huixing said that recognizing the enterprise's relative ownership in its property was the key to its autonomy. ${ }^{187}$ If Sino-foreign equity joint ventures own their property, state enterprises cannot be denied ownership of theirs. ${ }^{188}$ The state enterprise's ownership of its property is not private or collective ownership so it cannot harm the system of public ownership. ${ }^{189}$ Besides, the state retains macroeconomic and legal means to control the activities of state enterprises. ${ }^{190}$ In his pragmatism, however, Liang did not anticipate the theoretical difficulties in his proposition. In particular, he did not explain how one thing can have two different owners. This flaw has attracted the most

183. The State Council later issued its own regulations which prohibit state enterprises from issuing shares to the public. See State Council Notice Concerning Strengthening the Administration of Shares and Bonds, Guowuyuan gongbao (Bull. State Council), Mar. 28, 1987, at 346.

184. 2 Ye L., Falü Jianshe (Legal Construction) 46 (1987).

185. Id. The property of collective enterprises is owned by the members of the collective in indivisible shares. The nature of collective ownership, however, is ideological not practical for the shares in a collective enterprise are only national and cannot be transferred. Collective ownership is a type of public ownership. Thus, collective property is public property and should not be confused with family property or other types of private property which is co-owned.

186. Cf. Liang Huixing, A Discussion of the Enterprise Legal Person and the Enterprise Legal Person's Ownership Rights, in Certain Civil Law Problems in Reform of the Economic Structure 75 (Tong Rou ed. 1985).

187. Id. at 84 .

188. Id. at 85. Another theorist has relied on this anomaly in China's system of ownership to show that ownership rights need not always conform with the system of ownership and that this has also occurred in Czechoslovakia, in 1972 legislation on Czech-foreign mixed ownership companies: Xu Ming, A Discussion of Bankruplcy and Enterprise Legal Person Ownership, I Nw. INST. PoL. \& L. REv. 22 (1987), reprinted in 1 Collection of Newspaper and Journal Material (Economic Law) D411, 69.

189. Id.

190. Id. at 87. 
criticism, ${ }^{191}$ and since then, supporters of divided ownership have gone back to the basics of political economy to find a theoretical justification.

Here, ideas also abound, but there are two theories which seem to illustrate not only how Chinese theorists have gone back to Marx's analysis of property relations in a system of private ownership in an attempt to define the respective limits of state and enterprise ownership, but also how theoretical development has tended to expand the scope of enterprise ownership. The first theory, presented by a civil law teacher at the Chinese People's University, starts from the traditional premise that only the state has ownership in the means of production. ${ }^{192}$ Taking a Marxist view that commodities are the product of combining the means of production and labor, he concludes that the state enterprise enjoys "commodity ownership," i.e., ownership in the thing which has been produced by combining the stateowned means of production with labor provided by the body of workers. ${ }^{193}$ Because the enterprise is an assembly of workers which contributes labor to the process of production, it should therefore enjoy ownership in the product. ${ }^{194}$

By separating ownership in the means of production from commodity ownership, the first theory explains the theoretical basis for state enterprises to engage in commerce, but it does not justify enterprise autonomy from administrative intervention. However, a second theory later emerged which attempts to show that the duality of ownership Marx identified in the capitalist system is also able to define the relationship between the state and state enterprise in a socialist economy. ${ }^{195}$ In his Theories of Surplus Value, Marx showed that under capitalism, ownership had both legal and economic expressions which could be separated from each other. According to Lu Zhengping, this explains how in a share company the shareholders' property is a commodity performing an economic function (viz., profit making) in the hands of the company. ${ }^{196}$ The company thereby acquires independent legal personality and the legal rights to control its property. This results in a duality of property rights, i.e., the company's right to use its property and realize its value, and the shareholders' rights to share in the profits. ${ }^{197}$ This transformation of the company's character, he argues, was an important factor in the rapid economic development of capitalism.

191. Tong R. \& Zhou W., supra note 171

192. Wang Liming, Discussion of Commodity Ownership, 2 Studies in Law 37, 39 (1986).

193. Id.

194. Id. This appears to give the enterprise as a legal person the ownership in the products of the workers' labor which should belong to the workers themselves. This is precisely the kind of exploitation which led Yugoslav theorists to the concept of "social ownership," supra at note 41 and accompanying text.

195. Lu Zhengping, A Preliminary Discussion of the Duality of the Ownership of Property in Enterprises Owned by the Whole People, 3 Law Q. 36 (1986).

196. Id. at 37-38. See also Li Yuanzhi, A Tentative Discussion of the Ownership's Internal Vertical and Horizontal Structure, 1 Studies in LAW 51 (1986).

197. Id. at $37-38$. 
Lu notes that the system he describes obtains today in Western countries, even in the state-owned sector, where the state holds all or a majority of shares in state companies but does not directly interfere in the internal management of the company. ${ }^{198} \mathrm{He}$ then asserts that in China the relationship between the state, as investor, and the state enterprise is like that between shareholders and a company. The enterprise has independent control over its assets and bears sole liability for its losses. Thus, the state must not directly interfere in the internal management of the enterprise but can only influence the enterprise's economic activities by means of the planning mechanism, taxation, and other macroeconomic measures. This is really the crucial analogy Lu Zhengping wishes to draw, and it will have a special attraction for supporters of securitization of China's state enterprises. ${ }^{199}$ Thus, by another route, he comes to the same conclusion as advocates of different property rights.

Economic law theorists who deny that the state enterprise has any property rights at all can usually be identified with supporters of economic planning and rigorous state intervention in economic activities. Just as the theorists are not necessarily opposed to economic reforms, advocates of autonomous property rights in state enterprises are not necessarily opposed to state economic planning. It is clear, however, from the theoretical positions they have taken that each school of thought has its own view about the extent to which state enterprises should enjoy autonomy as well as the theoretical means to achieve it.

\section{Conclusion}

The General Principles is not just a piece of legislation; it represents a system of legal relations, and it has an underlying theoretical framework. Despite any special "Chinese characteristics" that might be found elsewhere in the General Principles, its theoretical framework is firmly rooted in the Romanist law tradition as interpreted by the Pandectists and borrowed from them by Japanese and Chinese jurists before 1949. This is amply illustrated by the definition of property rights in chapter 5 , section 1. Although these property rights are the product of new property relationships based on a mixed system of public and private ownership, Chinese civil law scholars analyze them with the same theoretical tools as their counterparts in capitalist countries. This is one illustration of Pashukanis' thesis that law is by its definition bourgeois and that the search for so-called socialist legal forms is fruitless. Indeed, Chinese theorists are not disturbed that the analysis of ideal socialist property

198. Id. at 38.

199. Lu's view appears to be gaining currency among other theorists such as Wang Liming, who has apparently modified his theory of commodity ownership, see supra note 192, to accommodate the transformation of some state enterprises into stock equity enterprises owned in shares by the state, enterprise employees, and members of the public, see supra note 110 . 
relations with tools invented for capitalist forms is not always a comfortable fit.

Article 82 of the General Principles broadly defines the property relations between the state and the state enterprise, but the nature and extent of property rights vested in the state enterprise are still the subject of theoretical controversy. Is the "right to operate" a property right at all, or is it merely an authority to use public property as directed by the state? Are they real rights vested in the enterprise which can thus control state property to the exclusion of even state administrative intervention? Or is ownership in public property shared by the state and the enterprise? In either case, is the state thereby deprived of the right to control enterprise property except by using macroeconomic measures? These are all possibilities debated by theorists in the search for a legal definition of enterprise autonomy. This lack of a clear theoretical basis for state enterprise property rights will remain an obstacle to reform of the state-owned industrial sector of China's economy.

\section{VI}

\section{Afterword}

Research for this article was completed in the summer of 1987. Had it not been for the democracy movement in the spring of 1989 and its violent political aftershock, the pattern of theoretical development I have described above would have been confirmed by the important ideological and legal developments which followed the CCP Central Committee's annual plenum in the fall of 1987. However, the dismissal in July 1989 of CCP General Secretary Zhao Ziyang, former Premier and chief architect of China's program of economic reform, has cast doubt on the future course of China's socioeconomic development. Although the ultimate consequences of recent political developments are far from clear, it has become necessary briefly to reassess the direction of economic and ideological change in China as well as its effects on past and future legal developments.

Already in 1988, the appointment of $\mathrm{Li}$ Peng to replace Zhao Ziyang as China's Premier was a challenge to existing economic policy. $\mathrm{Li}$, who studied in the Soviet Union in the 1950's, is commonly associated with conservative economic policies which favor central planning and strict administrative control over the economy. Such policies are at odds with the economic freedoms which arose in the 1980's and the system of property rights designed to foster them. Although China's new leadership remains publicly committed to foreign trade and investment policies, ${ }^{200}$ its commitment to the relatively free domestic economy is far from clear. Soon after the political reshuffling which took place in the wake of the Tiananmen massacre, the policies of Zhao Ziyang and his intellectual allies were vilified in internal Party

200. Do Rosario, Banker's Acceptance, FAR EASTERn Econ. Rev. 48 (Nov. 2, 1989). Facing a serious foreign exchange shortfall for 1990, China has little choice but to continue its foreign economic policies. Do Rosario, Foreign Accounting, FAr EASTERn Econ. Rev. 56 (July 27, 1989). 
documents as well as in China's press. ${ }^{201}$ At the same time, newly emerging economic policies signal a return to central economic management. ${ }^{202} \mathrm{~A}$ recent crackdown on non-agricultural private enterprise, although perhaps conceived as retribution for those entrepreneurs who gave economic anc moral support to the democracy movement, does not bode well for the future development of economic freedom. ${ }^{203}$

Before 1978, anyone who suggested a loosening of the strict adherence to state and collective modes of production was labelled a revisionist or a capitalist roader. Over the last decade of economic reform, as reformers sought ways to realize economic potential by reinventing private property rights, the CCP leadership found it necessary to put itself above such criticism and began to nurture an ideology for the economically underdeveloped socialist state. Although this new ideology began with a theory posited as early as 1979,204 it was not until the Thirteenth CCP National Congress in October 1987 that "preliminary socialism" was pronounced a part of official ideology. In his speech to the Congress, the central ideological proclamation, former General Secretary Zhao Ziyang explained that because socialist China emerged from a semi-colonial, semi-feudal period without passing through a stage of highly developed capitalism, its productive forces remained far behind those of developed capitalist countries. ${ }^{205}$ Therefore, he declared, China would first have to go through a long period of preliminary socialism during which time the private economy would be allowed to co-exist with the socialist public economy. ${ }^{206}$

Applied to law, the doctrine of preliminary socialism lends ideological legitimacy to legal ideas and forms borrowed from the West, without having the appearance of undermining socialism or the authority of the CCP. In fact, it is clear that the influx of Western political ideals into China inspired young Chinese intellectuals boldly to demand political changes which a majority of China's Party elders are still not prepared to concede. Inevitably, Western ideas will again be criticized as a cause of "bourgeois liberalization" among Chinese intellectuals. ${ }^{207}$ It is true that adverse political responses to unrest amongst intellectuals in the past decade have been relatively short-lived and have not deterred China's jurists from studying Western law and borrowing

201. Do Rosario, Settling Old Scores, Far Eastern Econ. Rev. 13 (Aug. 10, 1989); Delfs, Fixing the Line, Far Eastern Econ. Rev. 14 (Nov. 9, 1989).

202. Do Rosario, Quick Step Back, Far EAStern Econ. Rev. 47 (Oct. 19, 1989). An outline of the new economic policy appeared in a secret Party document which was probably a product of the Fifth Plenum of the CCP Central Committee in the fall of 1989. See Delfs, Power to the Party, FAR EASTERN ECoN. Rev. (Dec. 7, 1989).

203. Do Rosario, To Pay Tax is Glorious, Far Eastern Econ. Rev. 51 (Aug. 24, 1989).

204. See Su Shaozhi, Xueshu yuekan (ACademic Monthly), June 1979, at 14; Sullivan, Ideology of the CCP Since the Third Plenum, in Chinese MARXism In Flux 1978-1984 (B. Brugger ed. 1985).

205. Advance Along a Socialist Road with Chinese Characteristics, in Zhongcuo GongChandaNG DI Shisanci Quanguo diabiao Dahui wenjIan huibian (Collected Documents of the 13th National Congress of the CCP) 1 (1987).

206. Id.

207. Compare, e.g., Campus Unrest: Result of Liberalization, 8 BEIJing Rev. 14 (1987) (criticism of the student democracy movement of winter 1986). 
from it. However, just as the democracy movement of 1989 was wider and deeper than ever before, the present political campaign will run longer and deeper. It seems unlikely that the doctrine of preliminary socialism will survive the 1990 CCP Congress but even if it does, China's jurists will find little comfort in it as a blanket approval for foreign legal borrowings.

Legal changes made on the strength of preliminary socialism are therefore threatened. In April 1988, the National People's Congress took two important steps to give legal expression to urban economic reforms. The first and most fundamental was to amend the 1982 Constitution expressly to permit and protect the private economy (siying jingji) ${ }^{208}$ and the lawful transfer of the right to use land. ${ }^{209}$ Any doubt about the constitutionality of existing laws ${ }^{210}$ on these topics was thereby put to rest. Second, after a long gestation, a comprehensive law was promulgated to regulate state-owned enterprises. ${ }^{211}$ The State Enterprise Law was supposed to be a crucial development in the public economy for two reasons. First, it was supposed to define the structure necessary to give the state enterprise its economic autonomy. Second, the State Enterprise Insolvency Law ${ }^{212}$ and the State Enterprise Law were parts of a single reform package with the implementation of the former contingent on the latter. ${ }^{213}$

In fact, the State Enterprise Law is a disappointment because while the enterprise management can in name make economic decisions more autonomously, the exercise of this power is still ambiguously open to interference from Party and government organs. ${ }^{214}$ The powers of the factory director/manager and the procedure for his/her appointment is left for clarification by the State Council. ${ }^{215}$ Property rights in the state enterprise have been defined but not in detail and this makes the future of the draft State Enterprise Property Management Regulations ${ }^{216}$ uncertain. Enterprise property rights are set out in the same terms as article 82 of the General Principles 217 " according to the principle of separation of ownership and the

208. Chinese Const., art. 11.

209. Id. art 10.

210. On pre-existing legislation concerning land use rights, see Sobel \& Zhang, supra note 88, at Part VIII. On legislation regulating the individual economy, see Epstein \& Ye, Individual Enterprise in Contemporary Urban China: A Legal Analysis of Status and Regulation, 21 INTERNAT'L LAWYER 397 (1987). On 1988 legislation regulating the private economy, see Provisional Regulations Concerning Private Enterprises, Provisional Regulations Concerning Income Tax on Private Enterprises, Provisions Relating to the Imposition of Individual Income Regulatory Tax on Investors in Private Enterprises, in EAST AsIan ExECuTIVE RePorts (Oct. 1988); Conner, China's Provisional Regulations Governing Private Enterprises, in id.

211. Law of the PRC for Enterprises Owned by the Whole People, People's Daily (overseas ed.), Apr. 18, 1988 , at 3 .

212. See supra note 89.

213. The State Enterprise Insolvency Law was designated to come into effect three months after the State Enterprise Law was implemented, i.e., Nov. 1, 1988.

214. See Chinese Const., arts. 8, 55.

215. See id. art. 67 , chs. $3,4$.

216. See supra note 178.

217. See supra text accompanying notes $165-69$. 
right to operate." 218 The latter is defined as "the right of an enterprise to possess, use, and dispose of property according to law." 219

Of course, this definition closely coincides with the constituents of ownership in the General Principles, ${ }^{220}$ except that it does not include mention of "benefit" and adds the apparently superfluous rider that disposition of property must be "according to law." If the rights to possess, use, and even dispose of property, while limited to certain situations, constitute the only benefit enjoyed by the enterprise from its property, this formulation of the "right to operate" weakens the view that the state enterprise's property right is a kind of usufruct. ${ }^{221}$ Conferring on the enterprise the ultimate right of disposition, however, suggests the right to operate is a "property right" but qualifying disposition clearly preserves powers of administrative intervention at the expense of enterprise autonomy. Ultimately, management autonomy still depends on who is making the enterprise's economic decisions and in this respect the law is still far from clear.

Even "preliminary socialism" cannot accommodate theories about the system of ownership which go to the root of Marxist orthodoxy. Nevertheless, radical theories about the transformation of property in state enterprises remained, until the summer of 1989 at least, hot topics for discussion. ${ }^{222}$ Thus, the advent of preliminary socialism made it appear that state ownership was a waning economic significance. However, after the State Council prohibited state enterprises from issuing shares, ${ }^{223}$ it seemed clear that reforming state ownership by the securitization of state enterprises was not an immediate possibility. While the State Enterprise Law has not lifted this prohibition, ${ }^{224}$ it does seem to envisage that some state enterprises will be owned by shares ${ }^{225}$ and can hold shares in other enterprises and institutions. ${ }^{226}$

Finally, the dramatic political events which took place in Eastern Europe during the winter of 1989 will affect China's pattern of legal borrowings. Unless China soon follows the political path of Eastern Europe, which seems highly unlikely, the legal reforms which will inevitably accompany political and economic change in Eastern Europe will be too radical to be an acceptable model for China. The borrowing of legal ideas from Hungary and East Germany will thus cease. As the economic policies of Zhao Ziyang's China had already surpassed the Soviet Union, where political direction is also fraught with uncertainty, China may be forced into ideological isolation. This may force legal thinkers to look harder for indigenous solutions to China's

\footnotetext{
218. State Enterprise Law, art. 2. Any theory of relative ownership is thereby rejected.

219. Id.

220. See supra Part III.A.

221. See supra Part IV.B.2.i.

222. See Li Yining, supra note 180; Delfs, Property to the People, Far Eastern Econ. Rev. 12 (Dec. $22,1988)$.

223. See supra note 183.

224. Article 34 provides that the state enterprise may issue bonds but does not mention shares.

225. Chinese Const., art. 66.

226. Id. art. 34 .
} 
legal problems. More likely, as economic management is recentralized, economic reform in the secondary and tertiary sectors will stall and discarded ideas will be "rediscovered" and applied to the problems of the old economic system. Civil law, which flourished as market forces were reasserted after 1984, may now be supplanted by economic law, marking the reascendency of the public economy. 